\title{
1 Source patterns of Potentially Toxic Elements (PTEs) and mining activity \\ 2 contamination level in soils of Taltal city (Northern Chile)
}

\author{
Arturo Reyes 1,2,a, Matar Thiombane ${ }^{3,4, a, b}$, Antonio Panico5 ${ }^{5}$ Linda Daniele ${ }^{6}$, Annamaria Lima ${ }^{3}$, \\ Marcello Di Bonito 7 , Benedetto De Vivo4,5 \\ 1 Departamento de Ingeniería en Minas. Universidad de Antofagasta, Antofagasta. Chile \\ 2 Centro de Investigación Científico Tecnológico para la Minería, CICITEM, Antofagasta, Chile \\ 3 Dipartimento di Scienze della Terra, dell'Ambiente e delle Risorse, Università degli Studi di Napoli \\ "Federico II", Complesso Universitario Monte S. Angelo, Via Cintia snc, 80126 Naples, Italy \\ ${ }^{4}$ Norwest Italia Srl, 80138, Napoli, Italy \\ 5 Pegaso University, Piazza Trieste e Trento 48, 80132 Naples, Italy \\ ${ }^{6}$ Departamento de Geología, Universidad de Chile - Plaza Ercilla 803 - Santiago, Chile \\ 7 School of Animal, Rural and Environmental Sciences, Brackenhurst Campus Southwell NG25 0QF \\ Nottingham Trent University, United Kingdom \\ a First authors with equal contribution \\ b Corresponding author. E-mail address: thiombane.matar@unina.it (M. Thiombane)
}

\section{Highlights}

- High concentrations of PTEs are displayed in the north-eastern part of Taltal city

- Abandoned mining waste deposits are the main source of PTEs in the study area

- Very high contamination level is displayed in soils nearby mining waste deposit (S1)

\section{Abstract}

Mining activities are amongst the main sources of Potentially Toxic Elements (PTEs) in the environment which constitute a real concern worldwide, especially in developing countries. These activities have been carried out for more than a century in Chile, South America, where, as evidence of incorrect waste disposal practices, several abandoned mining waste deposits were left behind. This study aimed to understand multi-elements geochemistry, source patterns and mobility of PTEs in soils of the Taltal urban area (northern Chile). Topsoil samples $(n=125)$ were collected in the urban area of Taltal city $(6$ $\mathrm{km}^{2}$ ) where physicochemical properties (Redox potential, Electric conductivity and $\mathrm{pH}$ ) as well as chemical concentrations for 35 elements were determined by inductively coupled plasma optical emission spectrometer (ICP-OES). Data were treated following a robust workflow, which included Factor Analysis (based on ilr-transformed data), a new Robust Compositional Contamination Index (RCCI), and Fractal/multi-fractal interpolation in GIS environment. This approach allowed to generate significant 
elemental associations, identifying pool of elements related either to the geological background, pedogenic processes accompanying soil formation or to anthropogenic activities. In particular, the study eventually focused on a pool of 6 PTEs ( $\mathrm{As}, \mathrm{Cd}, \mathrm{Cr}, \mathrm{Cu}, \mathrm{Pb}$, and $\mathrm{Zn}$ ), their spatial distribution in the Taltal city, and the potential sources and mechanisms controlling their concentrations. Results showed generally low baseline values of PTEs in most sites of the surveyed area. On a smaller number of sites, however, higher values concentrations of $\mathrm{As}, \mathrm{Cd}, \mathrm{Cu}, \mathrm{Zn}$ and $\mathrm{Pb}$ were found. These corresponded to very high RCCl contamination level, and were correlated to potential anthropogenic sources, such as the abandoned mining waste deposits in the north-eastern part of the Taltal city. This study highlighted new and significant insight on the contamination levels of Taltal city, and its links with anthropogenic activities. Further research is considered to be crucial to extend this assessment to the entire region. This would provide a comprehensive overview and vital information for the development of intervention limits and guide environmental legislation for these pollutants in Chilean soils.

Keywords: Taltal city; Chile; Mining waste deposits; PTEs; contamination level; RCCI

\section{Introduction}

Environmental geochemistry aims to reveal inorganic elements sources and discriminate anthropogenic pollution to natural (geogenic) source (Lima et al., 2003; Albanese et al., 2007; Reimann et al., 2008) which can release contaminants into atmospheric, soil and water media (Prapamontol and Stevenson, 1991; Suchan et al., 2004). Industrial activities, domestic, livestock and municipal wastes, agrochemicals, and petroleum-derived products can all be sources of chemicals and contaminants (Reimann and De Caritat, 2005; Luo et al., 2009; Bundschuh et al., 2012). However, some sources of potentially toxic elements (PTEs) and contamination in urban area might be also related to geogenic (i.e., natural) backgrounds (Cicchella et al., 2005; Biasioli et al., 2007; Luo et al., 2012). In fact, several soil parent materials are natural sources of PTEs, which can pose a risk to the environment and human health when at elevated concentrations. Urban soil pollution is one of the most challenging environmental issues to tackle due to its impact to human health and the ecosystem (Cicchella et al., 2005; Albanese et al., 2010; Petrik et al., 2018a). In addition, PTEs are increasing due to accelerated population growth rate, higher level of urbanisation and industrialisation, providing a great variety of anthropogenic contamination/pollution sources (Wang et al., 2012; Wu et al., 2015; Guillén et al., 2017). In order to address these challenges, a variety of geostatistical computations and mapping tools have been developed and used to identify sources and patterns of different PTEs, to isolate their provenance 
compared to underlying geological features and/or anthropogenic activities (Albanese et al., 2007; Reimann et al., 2008, Thiombane et al., 2018a), and therefore assess the potential contamination levels in a meaningful way. A Large number of indices aimed to quantify contamination levels into environment, such as the Enrichment factors (Chester and Stoner, 1973), the Geoaccumulation Index (Müller, 1969) and the Single Pollution Index (Hakanson, 1980; Müller, 1981). But, authors such Reimann and de Caritat $(2000,2005)$, Petrik et al. (2019) have clearly demonstrated that indices (e.g., Enrichment factor and Pollution Index) using background/baseline values for reference) "are straightforward, but are not scale-invariant, which means that changes in units of the measured concentrations will modify the results of the analysis" (Aitchison and Egozcue, 2005; Pawlowsky-Glahn and Buccianti, 2011; Pawlowsky-Glahn et al., 2015). Moreover, Element ratio variations and Enrichment factors (EFs) values can vary depending on the different parent rock materials and chosen reference media as well as reference elements (Reimann and de Caritat, 2000; 2005). In addition, these indices do not take into account the different biogeochemical processes, the natural fractionation of elements or differential solubility of minerals (Sucharovà et al., 2012) which may have remarkable impact on elemental enrichment/contamination (Reimann and de Caritat, 2000, 2005). In order to address some of these issues, Petrik et al. (2018a) introduced a new contamination index called Robust Compositional Contamination Index (RCCl) that considers the compositional structure of the data (Aitchison and Egozcue, 2005; Pawlowsky-Glahn and Buccianti, 2011; Pawlowsky-Glahn et al., 2015) avoiding outlier's artefacts.

Among anthropogenic activities, mining activity is considered a major environmental issue worldwide, especially in developing countries (Ezeigbo and Ezeanyim, 1993; Lim e al., 2008; Naicker et al., 2003; Azevedo-Silva et al., 2016) due to releases of mining tailings and polluted wastewater into soils, atmosphere and hydrosphere and their long-lasting consequences. Such mining activities have been carried out for a long time in Chile. In particular, over the past 100 years they were intensified by the industrial acceleration, leaving behind a plethora of testimonies of incorrect waste disposal practices, including several abandoned sites containing mining waste with elevated concentrations of PTEs. This situation is particularly serious in the region of Antofagasta, northern Chile, characterized by the presence of a high density of mining operations. A case study of great concern is the Taltal city (Antofagasta region), where the CENMA (2014) has reported the occurrence of a large number of $\mathrm{Cu}$ and Au-related abandoned mining waste deposits in its proximity. Over the years, the Taltal city has considerably expanded, causing uncontrolled urbanisation, encroaching these abandoned sites of mining wastes that may be a real concern for local population directly exposed to PTEs-related mining tailings. The main aim of this study is to identify possible contamination impacts of these abandoned mining waste deposits in soils of the Taltal city. In order to achieve this aim, the main objectives are: 
(1) To measure multi-elements concentration level in soils of the Taltal city, and their spatial distributions in the study area;

(2) To determine the background/baseline concentration of 6 PTEs;

(3) To quantify the effect of abandoned mining waste deposits in soils of the Taltal city, and

(4) To assess the contamination level in topsoil of Taltal urban area, based on a robust compositional index of the 6 considered PTEs

This study presents an analysis of the spatial abundance of 6 PTEs in soils of Taltal city which will be assessed by applying the new RCCl that honours the compositional structure of the data. This survey is important because it constitutes the first study carried out on soils of Taltal city and can be considered a stepping stone towards a more detailed and meaningful investigation on potential sources and levels of PTES in this area. Further research would be crucial to extend the same approach to the entire region, to provide vital information for future developments of environmental legislation for defining intervention limits of these pollutants in Chilean soils.

\section{Materials and methods}

\subsection{Geological features and landuse of the study area}

The Taltal Municipality, covering an area of about $20,400 \mathrm{~km}^{2}$, is located in northern Chile, in the southern part of the Antofagasta region, within the Atacama Desert, and bordered on its western part by the Pacific Ocean (Fig. 1A).

[Figure 1 about here]

The main geological features of the Taltal municipality are constituted by two volcanic deposits called "La Negra" formations, consisting of volcanic clasts (andesitic and andesitic-basaltic lavas) with intercalations of sandstones (sandstones, tuffites and breccia, fine-grained to locally calcareous, composed by volcanic clasts) (Escribano et al., 2013) (Fig. 1B). They shape two major mountainous geomorphologic domains: the Coastal Range, which can reach elevations up to 2,650 $\mathrm{m}$ and the Coastal Scarp, reaching up to $1,000 \mathrm{~m}$ (Escribano et al., 2013). Within these two geological features there intrude the "Aeropuerto" formation, composed of porphyritic, banded rhyolite with plagioclase, quartz and spherulite phenocrysts with a small outcrop. This covers a surface of more than $1.5 \mathrm{~km}^{2}$ in the north of the Taltal city and crosses the area with a NW-SE orientation. The area surveyed by this study (Taltal city) is mostly consisting of the eroded products of the "Negra" formation deposit, including alluvial and colluvial deposits containing mixed conglomerates, sandstones, breccia, and marine sedimentary sequence, whose underline part is composed of calcareous sandstones, mudstones and 
fossiliferous shales (Triassic-Early Jurassic, Escribano et al., 2013). Along the coast, outcrops of marine deposits, conglomerate, and calcareous sandstone dominate the geological features, where a succession of marine abrasion terraces and littoral cords can be found (Escribano et al., 2013).

The study was carried out in the main urban area of the Taltal municipality which hosts more than 17,000 inhabitants, where around $89 \%$ of the population is grouped in Taltal city, located in the Atacama Desert. The climate of the area is characterised by an annual average temperature of $18{ }^{\circ} \mathrm{C}$, almost total lack of precipitation and only occasional torrential rainfalls fall during the autumn season accompanied by winds blowing generally from north and north-west. In contrast with the extreme climatic condition, this region is known to be rich in ore deposits. The Antofagasta region hosts the main Cu porphyry systems district of the world and most of the mines districts in the Taltal municipality are from medium to large size exploitation and processing of $\mathrm{Cu}$ and $\mathrm{Au}$ ore deposits. Sadly, large amounts of abandoned mine waste are found in the surroundings of Taltal city, discharged there after being produced by Cu- and Au-related ores exploitation (CENMA, 2014). Mining activities have been carried out for more than 100 years, attracting workers and producing an uncontrolled expansion of the urban area, which ended up growing over and including abandoned mining wastes. Recent surveys have allowed identifying and characterising the three largest abandoned mining wastes deposits of the Taltal commune (S1, S2, and S3); one of them occurs within the Taltal city (S1), therefore posing risks of direct and indirect exposure for the local communities. Compared to the S1, S2 and S3, S4 is of medium size and is localised in the south-western part of the Taltal city. The geochemical composition of the abandoned mining waste deposits is still unknown, and then their characterisation may be crucial to prevent or control environmental pollution and human health risk to the local population.

\subsection{Sampling procedure and analyses}

A total of 125 topsoil samples was collected in the urban area of the Taltal city $\left(6 \mathrm{~km}^{2}\right)$ with an average sampling density of approximately one sample per $0.05 \mathrm{~km}^{2}$ (Fig. 2).

\section{[Figure 2 about here]}

The sampling procedure is based on the Geochemical Mapping of Agricultural and Grazing Land Soils (GEMAS) sampling procedure described by Reimann et al. (2014). Each topsoil sample (from 0 to 20 $\mathrm{cm}$ ground top layer) was made by homogenizing 5 subsamples at the corners and the centre of a 100 $\mathrm{m}^{2}$ square, collecting approximately $1.5 \mathrm{~kg}$ in total after removal of the impurities (stones, coarse materials, and other debris). The soil samples were collected from the backyard of private houses, 
parks, playgrounds and sidewalks of roads. At each sampling site the geographical coordinates system were recorded by geospatial positioning systems (GPS). Containers used to collect samples were made of high density polyethylene (Nalgene). Prior to their use, all of them were washed overnight with an acid solution $\left(\mathrm{HNO}_{3}, 4 \mathrm{~mol} / \mathrm{L}\right)$ and flushed with ultra-pure water. High purity chemicals and deionised water were used to prepare all the solutions. All air-dried soil samples were sieved through a $2 \mathrm{~mm}$ nylon sieve to remove some impurities (e.g. large stones) and finally stored in sealed polythene bags prior to conduct physical and chemical analysis. The $\mathrm{pH}$ was measured in a 1:2.5 (w/v) soil-deionized water suspension after $1 \mathrm{~h}$ long agitation (Pansu and Gautheyrou, 2006; Fuentes et al., 2014), with a WTW multimeter (Profline pH 3110 set 2 meter) equipped with a SenTix 41 pH electrode (Weilheim, Germany). The electrical conductivity (EC) was determined in a saturation extract with a WTW Tetra Con325 electrode and a Profline Cond 3110 Set 1 meter (Weilheim, Germany). The redox potential (Eh) was measured with a Pt-Ag/AgCl selective electrode on sample/deionized water suspensions at 1:2.5 ratio (w/v). The digestion of samples was performed by aqua regia extraction (ISO 11466) and concentrations were determined according to EPA 6020A with an inductively coupled plasma optical emission spectrometer (ICP-OES Agilent 5100, USA) in an accredited laboratory (ALS Life Sciences Chile S.A) for 35 elements (Ag, Al, As, B, Ba, Be, Bi, Ca, Cd, Co, Cr, Cu, Fe, Ga, Hg, K, La, Mg, Mn, $\mathrm{Mo}, \mathrm{Na}, \mathrm{Ni}, \mathrm{P}, \mathrm{Pb}, \mathrm{S}, \mathrm{Sb}, \mathrm{Sc}, \mathrm{Sr}, \mathrm{Th}, \mathrm{Ti}, \mathrm{TI}, \mathrm{U}, \mathrm{V}, \mathrm{W}$, and $\mathrm{Zn}$ ). The calibration of equipment was performed prior their use and reagent blanks were used for quality control. All the analytical results were obtained as averages of three replicates. Precision of the analysis was calculated using three in-house replicates, and two blind duplicates submitted by the authors. Accuracy was determined using ALS Life Sciences Chile S.A's in-house reference material (Table 1).

[Table 1 about here]

\subsection{Geostatistical computations}

Two packages of the R software, "Compositions" (Van Den Boogaart et al., 2011) and "Robcompositions" (Templ et al., 2011), were used for geostatistical computations. Univariate descriptive statistic was computed (minimum, maximum, mean, median, Standard deviation, Coefficient of Variation, kurtosis and skewness) using log-transformed data that was then back-transformed to describe the central tendency and variability of the investigated elements. Although the log-ratio transformation of data is more relevant in compositional data analysis, the summary statistics output expressed in the raw concentrations of single elements is also meaningful and more easily interpretable (Petrik et al., 2018a). A special emphasis was applied on 6 PTEs (As, $\mathrm{Cd}, \mathrm{Cr}$, $\mathrm{Cu}, \mathrm{Pb}$ and $\mathrm{Zn}$ ), trying to 
identify the correlation between individual PTEs and the soil physicochemical properties (with $\mathrm{pH}, \mathrm{EC}$, and potential redox) using Pearson correlation coefficients ( $r$ ) and the $p$-values (with significance level of $p<0.05)$.

\subsection{Geochemical mapping and robust factor analysis}

\subsubsection{Spatial distribution and baseline values of PTEs}

One of the main objectives of Geographical Information Systems (GIS) is to display spatial distribution elements in studies areas through interpolation technics, further, shows their possible sources. Different interpolated methods have been implemented to display spatial distribution of elements, reveal geochemical processes, separating anomalies from background values as well the highlighting elemental-sources patterns (Cheng et al., 1999; Lima et al., 2003; Luz et al., 2014). Conventional weighted average technique such as kriging and ordinary inverse distance Weighted (IDW) smooth the local variability of the geochemical data, whereas multifractal IDW creates a geochemical map in which information about the local variability is retained (Cheng et al., 1999; Lima et al., 2003). Moreover, Multifractal IDW interpolation preserves high frequency information, which is lost in any conventional moving average methods such as kriging and ordinary inverse distance Weighted (IDW) (Cheng et al., 1999). During interpolation and mapping of geochemical variables, both spatial association and scaling are taken into account. More detailed description of MIDW method as well as Concentration-Area (C-A) and Spectrum- Area (S-A) models and the state-of-art of these models have been clearly emphasized by several authors (Cheng et al., 1999; Lima et al., 2003; Albanese et al., 2007; Petrik et al., 2018b). For this study, one of the aims was to determine the spatial distribution of a group of PTEs $(\mathrm{Cu}, \mathrm{Zn}, \mathrm{Pb}$, As, $\mathrm{Cr}$ and $\mathrm{Cd}$ ) and their respective baseline values in the soils of the Taltal city. ArcGIS (ESRI, 2012) and GeoDAS (Cheng et al., 2001) software were used as the main GIS tools. In particular, GeoDAS ${ }^{\mathrm{TM}}$ provided interpolated geochemical maps by means of the multifractal inverse distance weighted (MIDW) technique (Cheng et al., 1999; Lima et al., 2003; Thiombane et al., 2018a, 2018b). The C-A fractal method (Cheng et al., 1994) that characterises image patterns and classifies them into components based on a C-A plot, was applied to set the concentration intervals of the interpolated surfaces generated by the MIDW method, and ArcGIS ${ }^{\mathrm{TM}}$ software was used for the graphical presentation of the results.

Different studies have been conducted to determine background/baseline concentrations of elements (Reimann et al., 2005; APAT-ISS, 2006; Tarvainen and Jarva, 2011; Cave et al., 2012; Ander et al., 2013) and through this survey, we show showing baseline concentration ranges (where 'baseline' indicates the actual content of an element in the superficial environment at a given point in time, as 
defined by Salminen and Gregorauskiene (2000)) were obtained using the spectrum-areas method (S-A plot), which preserves high frequency information (Cheng et al., 1999; Albanese et al.; 2007).

The S-A method is a fractal filtering technique, based on a Fourier spectral analysis (Cheng, 1999; Cheng et al., 2001), and is used to separate anomalies from background values starting from a geochemical interpolated concentrations map. It also uses both frequency and spatial information for geochemical map and image processing. Fourier transformation can convert geochemical values into a frequency domain in which different patterns of frequencies can be identified. The signals with certain ranges of frequencies can be converted back to the spatial domain by inverse Fourier transformation (Zuo et al., 2015; Zuo and Wang, 2016, Thiombane et al., 2019). The interpolated maps generated from geochemical data were then transformed into the frequency domain in which a spatial concentrationarea fractal method was applied to distinguish the patterns on the basis of the power-spectrum distribution. A log-log plot was used to show the relationship between the area and the power spectrum values on the Fourier transformed map of the power spectrum. The values on the log-log plot were modelled by fitting straight lines using least squares. Distinct classes can be generated, such as lower, intermediate, and high power spectrum values approximately corresponding to baseline values, anomalies, and noise of geochemical values in the spatial domain, respectively. The image, converted back to a spatial domain with the filter applied, shows patterns that indicate an area that represents baseline geochemical values of $\mathrm{Cu}, \mathrm{Zn}, \mathrm{Pb}, \mathrm{As}, \mathrm{Cr}$, and $\mathrm{Cd}$ in our study area.

\subsubsection{Factor analysis}

Factor analysis (FA) is the multivariate statistical tool that explains the correlation structure of the variables through a smaller number of factors (Reimann et al., 2002). In environmental geochemistry, FA has been successfully used to reveal the elements sources related to their main hypothetical origins (Albanese et al., 2007; Thiombane et al., 2018a). In this study, we have applied a robust FA and the main procedures as well as the usefulness of this method has been highlighted in several publications (Filzmoser et al., 2009a, Petrik et al., 2018b; Thiombane et al., 2018b). The different factors obtained through the Robust FA were studied and interpreted in accordance with their presumed origin, i.e. geogenic, anthropogenic or mixed (Reimann et al., 2002; Albanese et al.,2007).

The number of all measured elements (35) was reduced to 24 variables based on 2 main criteria: 1) the removal of elements with more than $50 \%$ of observation values below the detection limit (DL), and 2) choosing elements with a communality of extraction higher than $0.5(50 \%)$ or common variances $<0.5$ (e.g. Reimann et al., 2002). As a consequence, both descriptive statistic and factor analysis were performed on a reduced number of 24 variables. 
GeoDAS $^{\mathrm{TM}}$ was also used to produce interpolated geochemical maps of the normalised factor scores by means of the multifractal inverse distance weighted (MIDW) algorithm (Cheng et al., 1994; Lima et al., 2003). Considering that the factor scores values present negative and zero values which are not "log transformable", a min-max normalisation was applied by scaling the original data within a specified range of features (e.g., ranging from 1 to 100). Min-max normalisation is a linear transformation on the original data without changing their geometrical structure (Han and Kamber, 2001).

The concentration-area (C-A) fractal plot (Cheng et al., 1994, 2000; Cheng, 1999) was used to classify the interpolated factor score maps and capture the different spatial patterns. Computations (e.g. logratio transformations, regressions, and factor analysis) and graphical representations were implemented by the open source statistical software of $R$ and CoDaPack (Comas-Cufí and Thió-Henestrosa, 2011).

\subsection{Contamination insights}

\subsubsection{Robust Compositional Contamination Index (RCCl)}

The RCCl is expressed as follows in three different steps:

$$
\mathrm{Xi}=\frac{C i}{B n}
$$

Where $\mathrm{Xi}$ is the ratio obtained dividing concentration of the metal $(\mathrm{Ci})$ by the geochemical background/baseline $(\mathrm{Bn})$ of the element under consideration. In this study, Geometric mean (GeoM) of baseline values of each of six considered PTEs ( $\mathrm{As}, \mathrm{Cd}, \mathrm{Cr}, \mathrm{Cu}, \mathrm{Pb}$, and $\mathrm{Zn}$ ) is considered prior to mean value, due to the fact that GeoM considers the central tendency of the dataset and it's not affected by the presence of outlier's observations.

$$
Z i=\operatorname{GeoM}(X i)
$$

Where $\mathrm{Zi}$ is the result obtained by computing the geometric mean (GeoM) of each sampling location constituted of Xi.

$$
\mathrm{RCCI}=\frac{Z i}{Z \max } \times 100 \%
$$

Where $\mathrm{RCCl}$ symbolise the robust compositional contamination index and, $\mathrm{Zi}$ and $\mathrm{Zmax}$ represent the geometric mean of the sampling point i and the maximum geometric mean, respectively. 
299

300

301

302

303

304

305

306

307

308

309

310

311

312

313

314

315

316

317

318

319

320

321

322

323

324

325

326

327

328

329

330

331

The result range from 0 to $100 \%$ and highest grade of contamination is reflected by a $\mathrm{RCCl}$ value near $100 \%$.

\section{Results and discussion}

\subsection{Spatial distribution and source patterns of PTEs}

Table 2 shows descriptive statistic of the 24 elements. Looking at skewness and kurtosis values, it can be observed that variables are characterised by a right skewed distribution, except $\mathrm{V}$ (left-skewed).

[Table 2 about here]

This points out how raw data representation does not match well the "real" normal distribution mostly due the presence of outliers. This is one of the main reasons why for further computations in this study, all data were ilr-log transformed to express the normal data distribution, avoiding outliers' artefacts and spurious correlation (Egozcue et al., 2003; Filzmoser et al., 2009b; Hron et al., 2010). In terms of variability, elements display large difference of CV values ranging from $36.20 \%$ (Al) to $398 \%$ (Mo). This large CV values may be related to diversity of geological features and its physicochemical properties, anthropogenic activities that could drive the distribution of these elements in soils of the study area. Based on their spatial distribution, interrelationship as well as their harmful effect and adverse risk to human health, a specific emphasis was given on a pool of 6 PTEs (As, Cd, Cr, Cu, Pb and $\mathrm{Zn}$ ).

Figure 3 shows the spatial distribution of $\mathrm{Cu}, \mathrm{Zn}$, and $\mathrm{Pb}$ in soils of the Taltal city, with interpolated maps interval ranges classified by using the concentration-area fractal method (C-A plot, plots below).

\section{[Figure 3 about here]}

Copper concentration values (Fig. 3A) range from 43 to $6,708 \mathrm{mg} / \mathrm{kg}$ in soils of Taltal city, with a mean value of $766 \mathrm{mg} / \mathrm{kg}$. The highest values (between 2,412 and 6,708 $\mathrm{mg} / \mathrm{kg}$ ) were found mostly in the north-eastern part of the study area. This area corresponds also with one of the largest abandoned mining waste deposits (S1) (see figure 2) of the Taltal municipality. Given the nature of the mining activities, these $\mathrm{Cu}$ anomalies could be related to the presence of the specific mining waste deposit (S1) which may affect concentrations in adjacent soils of the north-eastern part of our surveyed area.

Figures $3 \mathrm{~B}$ and $3 \mathrm{C}$ present $\mathrm{Pb}$ and $\mathrm{Zn}$ values interpolated maps, ranging from 8.15 to $2,624 \mathrm{mg} / \mathrm{kg}$ with a mean value of $135 \mathrm{mg} / \mathrm{kg}$, and ranging from 45 to $2,241 \mathrm{mg} / \mathrm{kg}$ with a mean value of $224 \mathrm{mg} / \mathrm{kg}$, respectively. The lowest values of $\mathrm{Pb}$ (ranging from 8.15 to $42 \mathrm{mg} / \mathrm{kg}$ ) and $\mathrm{Zn}$ (ranging from 45 to 153 
$\mathrm{mg} / \mathrm{kg}$ ) are evident along the north-eastern part, corresponding to the inland external boundary of our surveyed area. Values for these two elements gradually increase going towards the centre of the urban area of Taltal city. These two elements can be related to anthropogenic activities such as industrial and vehicular emission releases, which are characteristic of the urban areas. Similar results were also described in Naples (Italy), being related to heavy traffic emission (Lima et al., 2003; Cicchella et al., 2005; Petrik et al. 2018b). The highest values of $\mathrm{Pb}$ and $\mathrm{Zn}$ were found both in the north-eastern part of our study area but in different locations. Similarly to $\mathrm{Cu}$, high values of $\mathrm{Pb}$ and $\mathrm{Zn}$ were located in the proximity of the abandoned mining waste deposit (S1); moreover, $\mathrm{Pb}$ displayed anomalous concentration along the north-eastern part of the coastal side of our study area. The CENMA (2014) has explained that the abandoned mining deposit (S1) in Taltal city "may be not only" made up of mine tailing wastes, but also of possible metallurgical industrial waste dumps (e.g. batteries leaching waste). Lead and $\mathrm{Zn}$ are essential materials in batteries (Linden, 1995) and anomalies of these two PTEs, in Taltal city, may be related also to industrial wastes.

The interpolated map of As shows values ranging from 5.07 to $334.8 \mathrm{mg} / \mathrm{kg}$ with a mean value of 37.5 $\mathrm{mg} / \mathrm{kg}$ (Fig. 4A).

\section{[Figure 4 about here]}

Arsenic displays anomalies in the south-western and north-eastern parts of the study area, where values range from 81.56 to $334 \mathrm{mg} / \mathrm{kg}$. It can be speculated that As patterns in Taltal city may be influenced by anthropogenic activities, such as industrial waste and mining tailing abandoned in past year. In fact, the south-western and north-eastern parts of the Taltal city are characterised by the presence of mining waste deposits (S1 and S4), as already highlighted by CENMA (2014). The latter might be indicated as the potential main sources of As in soils of our surveyed area. Figure 4B shows the distribution of $\mathrm{Cd}$, which presents high concentrations (ranging from 3.95 to $22.23 \mathrm{mg} / \mathrm{kg}$ ) in the north-eastern part of Taltal city, corresponding to the area where anomalous values of $\mathrm{Cu}, \mathrm{Zn}, \mathrm{Pb}$, and As are also found. On the other hand, spatial distribution of $\mathrm{Cr}$, ranging from 2.09 to $85.8 \mathrm{mg} / \mathrm{kg}$ with a mean value of $19.26 \mathrm{mg} / \mathrm{kg}$ presents a different spatial pattern compared to other PTEs ( $\mathrm{Cu}, \mathrm{Pb}, \mathrm{Zn}, \mathrm{As}$ and $\mathrm{Cd}$ ). The highest concentrations of $\mathrm{Cr}$ occur along the coast and south-western part of Taltal city, where marine deposits prevail (sandstone and claystone) (Figs. 4C, 1B). In this case, anomalies of $\mathrm{Cr}$ could be linked to geogenic enrichment of $\mathrm{Cr}$ in marine deposits of Taltal City. The $\mathrm{Cr}$, being an "heavy" element, resistant to alteration, would be enriched in marine sands as a "placer" concentrate (KabataPendias, 2011). Follow-up studies should be made to clarify better $\mathrm{Cr}$ higher concentrations in marine deposits of the study area. 
As a general observation, the mean concentration values of the 6 considered PTEs in soils of Taltal city was compared with those in others urban areas from published studies (Table 3). Although the natural (geological and climatic) characteristics are different among the various locations, these comparisons usually allow for useful insight.

\section{[Table 3 about here]}

Tume et al. (2008) conducted a survey on soils of the Talcahuano city (central Chile), and their study reported higher means values of $\mathrm{Cr}$ and $\mathrm{Zn}$, compared to those found in Taltal city. A similar study dealing with urban pollution, highlighted lower means values of As and $\mathrm{Zn}$ in soils of Sau Paulo (Brazil) (Figueiredo et al., 2007). When compared to studies of larger Asian cities, it can be seen that the means values of $\mathrm{As}, \mathrm{Cr}, \mathrm{Cd}, \mathrm{Cu}, \mathrm{Pb}$ and $\mathrm{Zn}$ in soils of Yibin city (China), Hong Kong (China) and Ulaanbaatar (Mongolia) presented lower mean value compared to those of the present study. Similarly, comparisons with studies conducted in three African cities, with the exception of $\mathrm{Cd}$ and $\mathrm{Cr}$, values of the present study all displayed higher concentrations ( $\mathrm{As}, \mathrm{Cu}, \mathrm{Pb}$, and $\mathrm{Zn}$ ) compared to those of urban soils of Ibadan (Nigeria), Annaba (Algeria) and Sfax (Tunisia). Even the large metropolitan area of Naples (Southern Italy) showed lower means values of $\mathrm{As}, \mathrm{Cd}, \mathrm{Cr}, \mathrm{Cu}, \mathrm{Pb}$, and $\mathrm{Zn}$ (Cicchella et al., 2005) compared to those of the present study. On the other hand, soils in Glasgow (Scotland) (AjmoneMarsan et al., 2008) and Palermo (Italy) (Marta et al., 2002) displayed higher means values of $\mathrm{Cr}$ and $\mathrm{Pb}$, as well as $\mathrm{Cd}, \mathrm{Cr}$ and $\mathrm{Zn}$, compared to corresponding elements in soils of Taltal city. The only element that consistently showed higher concentration values in the present study compared to those carried out elsewhere is therefore $\mathrm{Cu}$, which is consistent with the potential origin from abandoned mining waste derived from Cu bearing deposit.

\subsection{Correlation between PTEs and soils physicochemical properties}

Values of redox potential, $\mathrm{pH}$ and $(E C)$ ranged from 92.10 to $279 \mathrm{mV}$ with a mean value of $183 \mathrm{mV}$, from 6.86 to 9.89 with a mean 7.91 , and 13 to $109,400 \mu \mathrm{S} / \mathrm{cm}$ with a mean value of $12,550 \mu \mathrm{S} / \mathrm{cm}$, respectively (Table 2). A total of $93 \%$ of soils samples were classified as neutral to strongly alkaline. Furthermore, based on their respective CV values, redox potential $(\mathrm{CV}=19.75 \mathrm{mV})$ and $\mathrm{pH}(\mathrm{CV}=7.51)$ displayed low variability in the studied soils.

Table 4 shows the linear correlation (based on Pearson correlation, $r$ ) and the significance of the relationship between the 6 considered PTEs and the physicochemical properties of soils.

It was noticed that $\mathrm{As}$ and $\mathrm{Pb}$ present high positive correlation between them $(r=0.69)$ and with $\mathrm{Cd}$ (with As, $r=0.51$ and with $\mathrm{Pb} r=0.69$ ), $\mathrm{Cu}$ (with $\mathrm{As}, r=0.61$ and with $\mathrm{Pb}, r=0.61$ ) and $\mathrm{Zn}$ (with $\mathrm{Pb}, \mathrm{r}=$ 
0.48). This high correlation between the different PTEs points toward the same source, which in this case is likely to be related to anthropogenic activities.

\section{[Table 4 about here]}

With the exception of $\mathrm{Cr}$, it was noticed a negative high correlation $(r<-0.45)$ between the redox potential and $\mathrm{pH}$ with $\mathrm{As}, \mathrm{Cd}, \mathrm{Cu}, \mathrm{Pb}$ and $\mathrm{Zn}$. This observation is consistent with acid $\mathrm{pH}$ and reducing conditions where PTEs accumulate in soils. It is well known (e.g., Shuman, 1985; Violante et al. 2010) that concentrations of metals(loids) can increase in soils that are characterised by acid pH and low redox potential, which is mostly related to surface charge on oxides on $\mathrm{Fe}, \mathrm{Al}$ and $\mathrm{Mn}$ or precipitation as metal(loid) hydroxides (Stahl and James, 1991; Mouta et al., 2008). The mobility of elements such as $\mathrm{As}, \mathrm{Cd}, \mathrm{Cu}, \mathrm{Pb}$ and $\mathrm{Zn}$ in the studied soils seemed to be clearly correlated with physico-chemical conditions. This was confirmed also by the $p$-values $(p<0.05)$, where significant correlations were observed between redox potential and $\mathrm{pH}$ with all the 6 elements, whereas EC was correlated with As and $\mathrm{Cd}$.

\subsection{Factor analysis and elements behaviour}

The total variance of the 24 variables was $71.73 \%$ in the four-factor model, which was chosen based on the break-point on the scree-plot of all factors. The 4 factors, named F1, F2, F3 and F4, account for $34.18 \%, 18.34 \%, 10.02 \%$ and $8.67 \%$ variability, respectively (Table 5).

\section{[Table 5 about here]}

Variables with loadings over the absolute value of 0.5 were considered to describe the main composition of each factor. All variables hold communalities over 0.5 (50\% of variability) meaning that the 4 factor models capture fairly well the elemental interrelationships and their possible geogenic and/or anthropogenic sources. The 24 elements of the four-factor model were separated by positive and negative loadings and sorted in descending order:

$\mathrm{F} 1=\mathrm{Pb}, \mathrm{As}, \mathrm{Sb}, \mathrm{Ag}, \mathrm{Cd}, \mathrm{Cu}, \mathrm{Mo}, \mathrm{Ni}, \mathrm{Zn},-(\mathrm{Mg}, \mathrm{Al}, \mathrm{Ti}, \mathrm{Sc}, \mathrm{K}, \mathrm{Ca})$

$\mathrm{F} 2=\mathrm{Co}, \mathrm{Fe}, \mathrm{Mo}, \mathrm{Ni}, \mathrm{V},-(\mathrm{Ba}, \mathrm{Sr}, \mathrm{Ca}, \mathrm{Na}, \mathrm{K})$

$\mathrm{F} 3=\mathrm{Cr}, \mathrm{V}, \mathrm{Fe}$

$\mathrm{F} 4=\mathrm{Mn}, \mathrm{Be}$

The $\mathrm{F} 1$ association (Pb, As, Sb, Ag, Cd, Cu, Mo, Ni, Zn, - (Mg, Al, Ti, Sc, K, Ca)) accounts for the highest total variance $(34.18 \%)$ with good adequacy (eigenvalues $=9.15>1$ ) between the factor and its 
variables. Figure $5 \mathrm{~A}$ shows the interpolated map of factor scores $(\mathrm{F} 1)$, ranging from -1.73 to 2.96; high factor scores (ranging from 1.43 to 2.96) were mapped in the north-eastern part of the Taltal city where the abandoned mining waste deposit (S1) is found. This pool of elements is mostly made up of PTEs, and their behaviour in soils of Taltal could be mostly related to an anthropogenic activity such as the presence of the abandoned mining waste deposits (S1). Low factor scores (ranging from -1.73 to -0.48 ) were found mostly in the eastern part of our study area, corresponding to an antithetic elemental association including $\mathrm{Mg}, \mathrm{Al}, \mathrm{Ti}, \mathrm{Sc}, \mathrm{K}$, and $\mathrm{Ca}$. This association is likely to be related to a geogenic source, and corresponds to an area where alluvial and colluvial deposits occur, made up by mixed sedimentary and volcanic deposits underlined by calcareous sandstones (Escribano et al., 2013).

\section{[Figure 5 about here]}

The F2 association (Co, Fe, Mo, Ni, V, - (Ba, Sr, Ca, Na, K)) expressed $18.34 \%$ of the total variance with an eigenvalue of 4.42 , and factor scores ranging from -2.50 to 2.36 . High factor scores values of $F 2$ association (ranging from 1.34 to 2.36) were found in the north-eastern part of the study area (mostly along the coast), in proximity of the $S 1$ mining tailing deposit (Fig. 5B). A potential explanation for this association is related to the accumulation of PTEs ( $\mathrm{Co}, \mathrm{Ni}, \mathrm{Mo}$, and $\mathrm{V}$ ) linked with Fe hydroxides. In oxidizing conditions, sorption and coprecipitation of hydrated cations such $\mathrm{Co}, \mathrm{Ni}, \mathrm{Mo}$, and $\mathrm{V}$ is likely to occur by adsorption onto Fe oxy-hydroxide (Koschinsky et al., 2003). In particular, the highest concentrations of $\mathrm{Fe}(\mathrm{Fe}>202,254 \mathrm{mg} / \mathrm{kg}$ ) were found in areas where this association actually displays the highest factor scores values. The lowest factor scores loadings (from - 2.50 to -0.37 ) were mostly found in an area where occur marine, abrasion terrace deposits, and littoral cords deposits (Fig. 5B). The antithetic elemental association ( $\mathrm{Ba}, \mathrm{Sr}, \mathrm{Ca}, \mathrm{Na}$, and $\mathrm{K}$ ) is likely to be related to geogenic source, mostly pedogenic processes on abrasion terrace and littoral cords characterised by marine deposits, conglomerate, and calcareous sandstone of the study area.

Figure $5 \mathrm{C}$ shows the interpolated map of factor scores (F3), ranging from -3.35 to 4.20 , and it presents the highest values (from 1.96 to 4.20) mostly in the coastal areas. These values could be related to pedogenic processes in fine-size marine deposits, by sorption and coprecipitation of $\mathrm{Cr}$ and $\mathrm{V}$ with $\mathrm{Fe}$ oxy-hydroxides in oxidizing environment (Stahl and James, 1991. Mouta et al., 2008); Cr and V originating from ultrabasic rocks in the ocean may become "enriched" in marine sands similarly to a "placer" concentrate. However, further studies are needed to better understand the source patterns of $\mathrm{Cr}$, which in this area displays particularly high concentrations.

The F4 association ( $\mathrm{Mn}$ and $\mathrm{Be}$ ) accounted a total variance of $8.67 \%$ with an eigenvalue of 1.39 . The F4 factor score map (Fig. 5D) shows elevated values (ranging from 1.79 to 3.40 ), near the S1 abandoned 
mining waste deposit, mostly in deposits of marine origin. Pedogenic processes inducing accumulation of $\mathrm{Mn}$ and $\mathrm{Be}$ in this area could be linked to this association. Koschinsky et al. (2003) emphasized how hydrated cations such as $\mathrm{Be}^{2+}$ have strong affinity with $\mathrm{Mn}$-oxide in marine deposits.

In order to better distinguish and discriminate anthropogenic from geogenic sources of the considered 6 PTEs (As, $\mathrm{Cd}, \mathrm{Cr}, \mathrm{Cu}, \mathrm{Zn}$ and $\mathrm{Pb}$ ), a scatterplot of the covariate relationship between concentration values with their respective distance to the abandoned mining waste deposit (S1) was employed (Fig. $6)$.

\section{[Figure 6 about here]}

In detail, figures $6 \mathrm{~A}, 6 \mathrm{~b}$ and $6 \mathrm{C}$ are scatter plots, showing the variation of $\mathrm{Cd}, \mathrm{Cu}, \mathrm{As}, \mathrm{Zn}, \mathrm{Cr}$ and $\mathrm{Cd}$ concentrations values together with the distance of their corresponding sampling points from the abandoned mining waste deposits (S1). The regression models of $\mathrm{Cu}, \mathrm{Pb}, \mathrm{Zn}, \mathrm{Cd}$ and $\mathrm{As}$ concentration values with their corresponding distance seem to follow a negative relationship, which is consistent with a decrease of the concentrations of these PTEs with increasing distance from S1. Moreover, their Pearson values confirm negative correlations between $\mathrm{Cu}(r=-0.51), \mathrm{Pb}(r=-0.38), \mathrm{Zn}(r=-0.29), \mathrm{Cd}$ $(r=-0.24)$ and $A s(r=-0.41)$ and their corresponding distance from S1. This observation further indicates how anomalies and patterns of $\mathrm{Cu}, \mathrm{Pb}, \mathrm{Zn}, \mathrm{Cd}$ and $\mathrm{As}$ in soils of Taltal city are very likely to be driven by the occurrence of abandoned mining waste deposit (S1).

On the other hand, the scatter plot between $\mathrm{Cr}$ concentration values and its corresponding distance to S1 shows no correlation (no relationship, with $r=0.03$ ) (Fig 6C). This observation precludes a link of this element with the abandoned mining waste deposit, confirming that it is more probably related to other mechanisms, such as $\mathrm{Cr}$ concentrations in marine sands.

\subsection{Baseline values of PTEs and Contamination level of Taltal city}

Figure 7 (plot below) presents results of the S-A fractal technique, which was used to determine the spatial distribution of background/baseline values of $\mathrm{Cu}, \mathrm{Zn}, \mathrm{Pb}, \mathrm{As}, \mathrm{Cr}$, and $\mathrm{Cd}$ in soils of the Taltal city, and further distinguishes anthropogenic from geogenic contributions.

\section{[Figure 7 about here]}

Relatively low concentration values of $\mathrm{Cu}$ (ranging from 8.49 to $450 \mathrm{mg} / \mathrm{kg}$ ) (Fig. 7), Zn (ranging from 4.18 to $260 \mathrm{mg} / \mathrm{kg}$ ) (Fig. 8A), Pb (from 3.55 to $84.88 \mathrm{mg} / \mathrm{kg}$ ) (Fig. 8B), As (from 1.22 to $39.32 \mathrm{mg} / \mathrm{kg}$ ) (Fig. 8C), Cd (ranging from 0.048 to 0.67 ) (Fig. 8D) and $\mathrm{Cr}$ (from 1.02 to $19.93 \mathrm{mg} / \mathrm{kg}$ ) (Fig. 8E) were 
501 found in most parts of Taltal city, and can be considered as the natural background variation for the

502

503

504

505

506

507

508

509

510

511

512

513

514

515

516

517

518

519

520

521

522

523

524

525

526

527

528

529

530

531

532

533 diverse lithologies that made up soils of the area. In contrast, higher baseline values $\mathrm{Cu}(>2,612$ $\mathrm{mg} / \mathrm{kg}$ ), Zn (> $608 \mathrm{mg} / \mathrm{kg}$ ), Pb (from 428 to $926 \mathrm{mg} / \mathrm{kg}$ ), Cd (from 3.08 to $6.78 \mathrm{mg} / \mathrm{kg}$ ) were found in the proximity of the abandoned mining waste deposit (S1). Fig. 8C shows high baseline values of As (from 105 to $162.4 \mathrm{mg} / \mathrm{kg}$ ) in the north-eastern and south-western parts of Taltal city, where the S1 and S4 abandoned mining tailings deposits are located. Based on these observations, it can be speculated that higher baseline values of $\mathrm{Cu}, \mathrm{Zn}, \mathrm{Pb}, \mathrm{Cd}$ and $\mathrm{As}$ are related to the occurrence of abandoned mining waste deposits in the proximity of (S4) and (S1). On the other hand, anomalous baselines values of $\mathrm{Cr}$ shown along the coast confirm the interpretation that they could be related to pedogenic processes affecting geogenic sources.

\section{[Figure 8 about here]}

In order to highlight the contamination level in soils of our study area, $\mathrm{RCCl}$ was computed for the 6 considered PTEs (As, Cd, $\mathrm{Cr}, \mathrm{Cu}, \mathrm{Pb}$, and $\mathrm{Pb}$ ).

Figure 9 presents the RCCI interpolated calculations, where lower values $(\mathrm{RCCl}<15 \%)$ were found in the south and eastern parts of the study area, corresponding to a lower population density and no industrial activities. This part of the city of Taltal seems therefore not affected by any contamination.

\section{[Figure 9 about here]}

Medium RCCl values (ranging from $15 \%$ to $25 \%$ ) were found roughly in the inner and central parts of the study area. This relatively low contamination may be related to small anthropogenic activities (e.g. vehicular emission) that release additional quantities of the 6 considered PTEs in some areas of Taltal city. However, in this area, anthropogenic releases of the 6 PTEs into environment are not significant. Moderate ( $\mathrm{RCCl}$ values ranging from 25 to $40 \%$ ) and high (RCCI from 40 to $75 \%$ ) contamination levels were found in the north-eastern and south-western parts of the study area, characterised by an abundance of elements such as $\mathrm{As}$ and $\mathrm{Cr}$, and $\mathrm{Cu}$ and $\mathrm{Pb}$, respectively. Based on these observations, it can be established that high contamination levels are induced by two different anthropogenic inputs, where the abandoned mining waste of the south-western part of the study area are Au-mining tailings mostly rich in arsenopyrite (As) (S4), whilst the one in the north-eastern part is more closely linked to $\mathrm{Cu}$ mining tailings (S1). A follow-up study would be necessary to better clarify the geochemical composition, characterisation and possible identification of the specific type of mining wastes deposits (S1 and S4). 
The highest values $(\mathrm{RCCl}>75 \%)$ were found only in the north-eastern part $(\mathrm{Cd}>\mathrm{Pb}>\mathrm{Cu})$ of the study area. In particular, the predominance of $\mathrm{Cd}$ and $\mathrm{Pb}$ in soils confirms the findings of the CENMA (2014) that highlighted this area as hosting industrial waste deposits (e.g. batteries leaching made up of $\mathrm{Zn}$ and $\mathrm{Pb}$ alloys) in addition to mining tailings.

\section{Conclusion}

This study demonstrates with comprehensive mapping tools and geostatistical analysis, the source patterns that drive multi-elements in soils of the study area, where robust computations have helped to reveal the impact of abandoned industrial and mining waste deposits in soils of Taltal city, Chile.

Robust factor analysis, based on ilr-transformed data was performed to get an overview of elemental associations and allowed to better distinguishing pool of elements related to the geological background (e.g. Mg, Al, Ti, Sc, K, Ca, Ba, Sr, Ca, Na, K), pedogenic processes accompanying soil formation ( $\mathrm{Fe}$, $\mathrm{Mn}, \mathrm{Cr}, \mathrm{V}, \mathrm{Be}, \mathrm{Co}, \mathrm{Mo}, \mathrm{Ni}, \mathrm{V}$ ) and anthropogenic activities (e.g. Pb, As, Sb, Ag, Cd, Cu, Mo, Ni, Zn). Mapping tools (Fractal methods) allowed displaying spatial distribution of the considered 6 PTEs and the behaviours of $\mathrm{As}, \mathrm{Cd}, \mathrm{Cu}, \mathrm{Pb}$ and $\mathrm{Zn}$, associated with the presence of abandoned waste mining deposits as well as with the physicochemical conditions of soils. Chromium was associated to pedogenic processes of sorption and coprecipitation in fine-size deposits of marine origin. Low baseline values of PTEs were found in most of the survey area and high values were often very small in extent, except for some sites where the anthropogenic influence on soils is clearly evident, due to the potential influence of extensive abandoned mining waste deposits (e.g., north-eastern part of the Taltal city). The integrated approach used in this study allowed a more robust qualitative and quantitative evaluation of contamination level, highlighting very high contamination levels, where the findings from the various tools converge all in the same direction, pointing out a strong link with abandoned mining tailings and industrial waste deposits. Results from this study strongly suggest that a more detailed and thorough assessment of PTEs should be conducted for a comprehensive evaluation of human health risk due to PTEs exposure.

\section{Acknowledgements}

We appreciate the contribution (Software support) from Annalise Guarino, $\mathrm{PhD}$ student from the Department of Earth Sciences, Environment and Resources (DISTAR), University of Naples, "Federico II". This work was supported through two financial supports: 1) Funding from the Regional Council of Antofagasta under Project "Estudio de ingeniería para la remediación de sitios abandonados con potencial presencia de contaminantes identificados en la comuna de Taltal - BIP N³0320122-0" and by 
2) "Conicyt + Fondef/ Tercer Concurso Idea en dos etapas del fondo de fomento al desarrollo científico y tecnológico. Fondef/Conicyt 2016+ Folio (Código IT16M10031), Mapa de la línea base geoquímica para suelos en la comuna de Taltal: LIBAMET-Map Services".

\section{References}

Aitchison, J., Egozcue, J., 2005. Compositional data analysis: where are we and where should we be heading? Math. Geol. 37, 829-850.

Albanese, S., De Vivo, B., Lima, A., Cicchella, D., 2007. Geochemical background and baseline values of toxic elements in stream sediments of Campania region (Italy). J. Geochem. Explor. 93 (1), 21-34.

Albanese, S., De Vivo, B., Lima, A., Cicchella, D., Civitillo, D., Cosenza, A., 2010. Geochemical baselines and risk assessment of the Bagnoli brownfield site coastal sea sediments (Naples, Italy). J. Geochem. Explor. 105, 19-33.

Ander, E.L., Johnson, C.C., Cave, M.R., Palumbo-Roe, B., Nathanail, C.P., Lark, R.M., 2013. Methodology for the determination of normal background concentrations of contaminants in English soil. Sci. Total Environ. 454-455, 604-618.

APAT-ISS, 2006. Protocollo Operativo per la determinazione dei valori di fondo di metalli/ metalloidi nei suoli dei siti d'interesse nazionale. Revisione 0. Agenzia per la Protezione dell'Ambiente e per i Servizi Tecnici and Istituto Superiore di Sanita (in Italian).

Azevedo-Silva, C.E., Almeida, R., Carvalho, D.P., Ometto, J.P.H.B., de Camargo P.B.,Dorneles, P.R., Azeredo, Antonio, Wanderley, R.B., Olaf, M., Torres, J.P.M., 2016.Mercury biomagnification and the trophic structure of the ichthyofauna from aremote lake in the Brazilian amazon. Environ. Res. 151, 286296.

Batjargal, T., Otgonjargal, E., Baek, K., Yang, J.S., 2010. Assessment of metals contamination of soils in Ulaanbaatar, Mongolia. J. Hazard. Mater 184, 872-876.

Biasioli, M., Grčman, H., Kralj, T., Madrid, F., Diaz-Barrientos, E., Ajmone-Marsan, F., 2007.Potentially toxic elements contamination in urban soils: a comparison of three European cities. J. Environ. Qual. 36, 70-79.

Bundschuh, J., Litter, M.I., Parvez, F., Román-Ross, G., Nicolli, H.B., Jean, J.-S., Liu, C.-W., López, D., Armienta, M.A., Guilherme, L.R.G., Cuevas, A.G., Cornejo, L., Cumbal, L. Toujaguez, R. 2012. One century of arsenic exposure in Latin America: a review of history and occurrence from 14 countries. The Science of the Total Environment, 429: 2-35. https:// doi.org/10.1016/j.scitotenv.2011.06.024.

Cave, M.R., Johnson, C.C., Ander, E.L., Palumbo-Roe, B., 2012. Methodology for the determination of normal background contaminant concentrations in English soils. In: British Geological Survey Commissioned Report, CR/12/003, (41 pp.). http://nora.nerc.ac.uk/19959/. 
602

603

604

605

606

607

608

609

610

611

612

613

614

615

616

617

618

619

620

621

622

623

624

625

626

627

628

629

630

631

632

633

634

CENMA. 2014. Informe final Versión 5. Diagnostico regional de suelos abandonados con potencial presencia de contaminantes. Contrato № 618775-3-LP13. [Spanish]

Cheng, Q., 1999. Spatial and scaling modelling for geochemical anomaly separation. J. Geochem. Explor. 65, 175-194.

Cheng, Q., Agterberg, F.P., Ballantyne, S.B., 1994. The separation of geochemical anomalies from background by fractal methods. J. Geochem. Explor. 51, 109-130.

Cheng, Q., Bonham-Carter, G.F., Raines, G.L., 2001. GeoDAS: a new GIS system for spatial analysis of geochemical data sets for mineral exploration and environmental assessment. In: The $20^{\text {th }}$ Intern. Geochem. Explor. Symposium (IGES). Santiago de Chile. Vol. 6/5-10/5. pp. 42-43.

Chester, R., Stoner, J.H., 1973. Pb in particulates from the lower atmosphere of the eastern Atlantic. Nature 245, 27-28.

Cicchella, D., De Vivo, B., Lima, A., 2005. Background and baseline concentration values of elements harmful to human health in the volcanic soils of the metropolitan and provincial area of Napoli (Italy). Geochem. Explor. Environ. Anal. 5, 29-40.

Comas-Cufí, M., Thió-Henestrosa, S., 2011. CoDaPack 2.0: a stand-alone, multi-platform compositional software. In: Egozcue, J.J., Tolosana-Delgado, R., Ortego, M.I. (Eds.), CoDaWork'11: $4^{\text {th }}$ International Workshop on Compositional Data Analysis. SantFeliu de Guíxols.

Egozcue, J.J., Pawlowsky-Glahn, V., Mateu-figueras, G., Barcelo-vidal, C., 2003. Isometric logratio transformations for compositional data analysis. Math. Geol. 35 (3), 279-300.

Escribano, J., Martínez, P., Domagala, J., Padel, M., Espinoza, M.,Jorquera, R.,...Calderón, M. (2013).Cartas Bahía Isla Blanca yTaltal. Escala 1:100.000. Servicio Nacional de Geología y Minería, Carta Geológica de Chile, Serie Geología Básica, 164-165. 1-75. 1 mapa escala 1:100.000. Santiago.[Spanish].

ESRI (Environmental Systems Research Institute), 2012. ArcGIS Desktop: Release 10. Redlands, CA.

Ezeigbo HI., Ezeanyim BN. (1993). Environmental pollution from coal mining activities in the Enugu Area, Anambra State, Nigeria. Mine Water Environ., 12: 53-62.

Figueiredo, A.M.G., Nogueira, C.A., Saiki, M., Milian, F.M., Domingos, M., 2007. Assessment of atmospheric metallic pollution in the metropolitan region of São Paulo, Brazil. Environ. Pollut. 145,279-292.

Filzmoser, P., Hron, K., Reimann, C., 2009a. Principal component analysis for compositional data with outliers. Environmetrics 20 (6), 621-632.

Filzmoser, P., Hron, K., Reimann, C., 2009b. Univariate statistical analysis of environmental (compositional) data - problems and possibilities. Sci. Total Environ. 407, 6100-6108. 
635

636

637

638

639

640

641

642

643

644

645

646

647

648

649

650

651

652

653

654

655

656

657

658

659

660

661

662

663

664

665

666

667

Guillén, M.T., Delgado, J., Albanese, S., Nieto, J.M., Lima, A., De Vivo, B., 2011. Environmental geochemical mapping of Huelva municipality soils (SW Spain) as a tool to determine background and baseline values. J. Geochem. Explor. 109 (1-3), 59-69. https://doi.org/10.1016/j.gexplo.2011.03.003.

Guo, G.H., Wu, F.C., Xie, F.Z. \& Zhang, R.Q. 2012. Spatial distribution and pollution assessment of heavy metals in urban soils from southwest China. Journal of Environmental Sciences,24,410-418.

Hakanson, L., 1980. An ecological risk index for aquatic pollution control. A sedimentological approach. Water Res. 14 (8), 975-1001, https://doi.org/10.1016/0043-1354(80)90143-8.

Han, J., Kamber, M., 2001. Data Mining: Concepts and Techniques. Morgan-Kaufmann Academic Press, San Francisco.

Hron, K., Templ, M., Filzmoser, P., 2010. Imputation of missing values for compositional data using classical and robust methods. Comput. Stat. Data Anal. 54 (12), 3095-3107.

ISO 11466. ISO. Soil Quality. Extraction of Trace Elements Soluble in Aqua Regia. ISO 11466. 1995.

Jmone-Marsan, F., Biasioli, M., Kralj, T., Grcman, H., Davidson, C.M., Hursthouse, A.S., Madrid, L., Rodrigues, S., 2007. Metals in particle-size fractions of the soilsof five European cities. Environ. Pollut. $152,73-81$.

Kabata-Pendias, A., 2011. Trace Elements of Soils and Plants, fourth ed. CRC Press, Taylor \& Francis Group, LLC, USA, pp. 28-534.

Koschinsky A, Winkler A, Fritsche U. Importance of different types of marine particles for the scavenging of heavy metals in the deep-sea bottom water. Applied Geochemistry. 2003;18 (5):693-710

Li, X., Lee, S.L., Wong, S.C., Shi, W., Thornton, I., 2004. The study of metal contamination in urban soils of Hong Kong using a GIS-based approach. Environmental Pollution 129, 113-124.

Linden, D. Handbook of Batteries, McGraw-Hill, New York, 1995, pp. 32.1-32.11.

Lim, H.S., Lee, J.S., Chon, H.T., Sager, M., 2008. Heavy metal contamination and health risk assessment in the vicinity of the abandoned Songcheon Au-Ag mine in Korea. J. Geochem. Explor. 96 (2-3), 223-230. https://doi.org/10.1016/j.gexplo.2007.04.008.

Lima, A., De Vivo, B., Cicchella, D., Cortini, M., Albanese, S., 2003. Multifractal IDW interpolation and fractal filtering method in environmental studies: an application on regional stream sediments of Campania Region (Italy). Appl. Geochem. $18 \quad$ (12), 1853-1865. https://doi.org/10.1016/S08832927(03)00083-0.

Luo, X.S., Yu, S., Zhu, Y.G., Li, X.D., 2011. Trace metal contamination in urban soils of China. Science of the Total Environment 421-422, 17-30.

Luo, Y., Wu, L., Liu, L., Han, C. Li, Z. 2009. Heavy Metal Contamination and Remediation in Asian Agricultural Land. p. 9. Paper presented at MARCO Symposium, 2009, Japan. 
668

669

670

671

672

673

674

675

676

677

678

679

680

681

682

683

684

685

686

687

688

689

690

691

692

693

694

695

696

697

698

699

700

701

702

Luz, F., Mateus, A., Matos, J.X., Gonçalves, M.A., 2014. Cu-and Zn-soil anomalies in the NE Border of the South Portuguese Zone (Iberian Variscides, Portugal) identified by multifractal and geostatistical analyses. Natural Resources Research 23, 195-215

Maas, S., Scheifler, R., Benslama, M., Crini, N., Lucot, E., Brahmia, Z., Benyacoub, S., Giraudoux, P. 2010. Spatial distribution of heavy metal concentrations in urban, suburban and agricultural soils in a Mediterranean city of Algeria, Environmental Pollution 158(6):2294-2301.

Manta, D.S., Angelone, M., Bellanca, A., Neri, R., Sprovieri, M., 2002. Heavy metals inurban soils: a case study from the city of Palermo (Sicily), Italy. Sci. TotalEnviron. 300, 229-243.

Mouta, E.R. Soares, M.R., Casagrande, J.C. 2008. Copper adsorption as a function of solution parameters of variable charge soils. J. Braz. Chem. Soc. 19, 996-1009.

Müller, G., 1969. Index of Geoaccumulation in sediments of the rhine river. Geo Journal 2, 108118.

Müller, G., 1981. The heavy metal pollution of the sediments of Neckars and its tributary: a stock taking. Chem. Ztg. 105, 157-164.

Naicker K, Cukrowska E, Mccarthy TS (2003). Acid mine drainage from gold mining activities in Johannesburg, South Africa and environs. Environ. Pollut., 122: 29-40.

Odewande, A.A., and A.F. Abimbola. 2008. Contamination indices and heavy metal concentrations in urban soil of Ibadan metropolis, southwestern Nigeria. Environ. Geochem. Health 30:243-254.

Pawlowsky-Glahn, V., Buccianti, A., 2011. Compositional Data Analysis: Theory and Applications. John Wiley Sons.

Pawlowsky-Glahn, V., Egozcue, J.J., Tolosana-Delgado, R., 2015b. Modelling and Analysis of Compositional Data. John Wiley Sons, pp. 252.

Petrik, A., Thiombane, M., Lima, A., Albanese, S., Buscher, J.T., De Vivo, B. 2018a. Soil contamination compositional index: A new approach to quantify contamination demonstrated by assessing compositional source patterns of potentially toxic elements in the Campania Region (Italy). Applied Geochemistry. 96, 264-276.

Petrik, A., Thiombane, M., Albanese, S., Lima, A., De Vivo, B., 2018b. Source patterns of Zn, Pb, Cr and Ni potentially toxic elements (PTEs) through a compositional discrimination analysis: a case study on the Campanian topsoil data. Geoderma. 331, 87-99.

Prapamontol, T., Stevenson, D. 1991. Rapid method for the determination of organochlorine pesticides in milk. J. Chromatogr. 552, 249-257.

Reimann, C., Birke, M., Demetriades, A., Filzmoser, P., O'Connor, P., GEMAS Team, 2014. Chemistry of Europe's agricultural soils - part A: methodology and interpretation of the GEMAS data set. In: Geologisches Jahrbuch (Reihe B). Schweizerbarth, Hannover, pp. 528.

Reimann, C., de Caritat, P., 2000. Intrinsic flaws of element enrichment factors (EFs) in environmental geochemistry. Environ. Sci. Technol. 34, 5084-5091. 
Reimann, C., Filzmoser, P., Garrett, R., 2002. Factor analysis applied to regional geochemical data: problems and possibilities. Appl. Geochem. 17 (3), 185-206.

Reimann, C., Filzmoser, P., Garrett, R.G., Dutter, R., 2008. Statistical data analysis explained. In: Applied Environmental Statistics with R. Wiley, Chichester, pp. 362. Chemistry of Europe's agricultural soils - part A: methodology and interpretation of the GEMAS data set. In: Reimann, C., Birke, M., Demetriades, A., Filzmoser, P., O'Connor, P., GEMAS Team (Eds.), Geologisches Jahrbuch (Reihe B), Schweizerbarth: Hannover, pp. 528.

Reimann, C., Garrett, R.G., 2005. Geochemical background - concept and reality. Sci. Total Environ. $350,12-27$.

Salminen, R., Gregorauskiene, V., 2000. Considerations regarding the definition of a geochemical baseline of elements in the surficial materials in areas differing in basic geology. Appl. Geochem. 15, 647-653.

Shuman, L.M. 1985. Effect of ionic strength and anions on zinc adsorption by two soils. Soil Sci. Soc. Am. J. 50, 1438-1442.

Stahl, R.S.. James, B.R. 1991. Zinc sorption by B horizon soils as a function of pH. Soil Sci. Soc. Of Am. J. 55, 1592-1597.

Suchan, P., Pulkrabová, J., Hajslová, J., Kocourek, V., (2004). Pressurized liquid extraction in determination of polychlorinated biphenyls and organochlorine pesticides in fish samples. Anal. Chim. Acta. 520,193-200.

Sucharovà, J., Suchara, I., Hola, M., Marikova, S., Reimann, C., Boyd, R., Filzmoser, P., Englmaier, P., 2012. Top-/Bottom-soil ratios and enrichment factors: what do they really show? Appl. Geochem. 27, 138-145.

Tarvainen, T., Jarva, J., Johnson, C.C., Ottesen, R.T., 2011. Using geochemical baselines in the assessment of soil contamination in Finland. In: Demetriades, A., Locutura, J. (Eds.), Mapping the Chemical Environment of Urban Areas. Chichester, UK, John Wiley Sons Ltd., pp. 223-231.

Templ, M., Hron, K., Filzmoser, P., 2011. Rob-Compositions: Robust Estimation for Compositional Data. Manual and Package, Version 1.4.4.

Thiombane, M., Martin-Fernandez, J.A., Albanese, S., Lima, A., Doherti, A., De Vivo, B., 2018a. Exploratory analysis of multi-element geochemical patterns in soil from the Sarno River Basin (Campania region, southern Italy) through compositional data analysis (CODA). J. Geochem. Explor. 195, 110-120.

Thiombane, M., Zuzolo, D., Cicchella, D., Albanese, S., Lima, A., Cavaliere, M., De Vivo, B., 2018b. Soil geochemical follow-up in the Cilento World Heritage Park (Campania, Italy) through exploratory compositional data analysis and C-A fractal model. J. Geochem. Explor. 189, 85-99. 
Thiombane, M., Di Bonito, M., Albanese, A., Zuzolo, D., Lima, A., De Vivo, D. 2019. Geogenic versus anthropogenic behaviour of geochemical phosphorus footprint in the Campania region (Southern Italy) soils through compositional data analysis and enrichment factor. Geoderma. 335, $12-26$.

Tume, P., J. Bech, B. Sepulveda, L. Tume, and J. Bech. 2008. Concentrations of heavy metals in urban soils of Talcahuano (Chile): A preliminary study. Environ. Monit. Assess. 140:91-98.

Van Den Boogaart, K.G., Tolosana-Delgado, R., Bren, R., 2011. Compositions: Compositional Data Analysis. $\mathrm{R}$ Package Version 1. pp. 10-12. Available at: http://CRAN.Rprojectorg/package=compositions.

Violante, A., Cozzolino, V., Perelomov, L., Caporale, A., Pigna, M. 2010. Mobility and bioavailability of heavy metals and metalloids in soil environments J. Soil Sci. Plant Nutr. 10, 268-292.

Wali, A., Colinet, G., Khadhraoui, M. Ksibi, M. 2013. Trace Metals in Surface Soil Contaminated by Release of Phosphate Industry in the Surroundings of Sfax-Tunisia. Environmental research, engineering and management. Vol 65, No 3 http://dx.doi.org/10.5755/j01.erem.65.3.4865.

Wang, Y., Sikora, S., Kim, H., Dubey, B., Townsend, T., 2012. Mobilization of iron and arsenic from soil by construction and demolition debris landfill leachate. Waste Manag. 32 (5), 925-932. https://doi.org/10.1016/j.wasman.2011.11.016.

Wu, S., Peng, S., Zhang, X., Wu, D., Luo, W., Zhang, T., Zhou, S., Yang, G., Wan, H., Wu, L., 2015. Levels and health risk assessments of heavy metals in urban soils in Dongguan, China. J. Geochem. Explor. 148, 71-78. https://doi.org/10.1016/j.gexplo.2014.08.009.

Zuo, R., Wang, J., 2016. Fractal/multifractal modelling of geochemical data: a review. J. Geochem. Explor. 164, 33-41. Zuo, R., Wang, J., Chen, G., Yang, M., 2015. Identification of weak anomalies: a multifractal perspective. J. Geochem. Explor. 148, 12-24.

Zuo, R., Wang, J., Chen, G., Yang, M., 2015. Identification of weak anomalies: a multifractal perspective. J. Geochem. Explor. 148, 12-24.

\section{Figure and table captions - Figures}

Figure 1. Geo-localisation of the Taltal city (Fig. 1A), main geological features (Fig. 1B) and Landuse (Fig. 1C) of the surveyed area

Figure 2. Sampling points and location of the abandoned mining waste deposits (S1, S2, S3 and S4) in (around) the study area

Figure 3. Interpolated maps of $\mathrm{Cu}, \mathrm{Zn}$, and $\mathrm{Pb}$ concentrations values in the survey area; ranges of concentration are based on the C-A fractal plots held bellow

Figure 4. Interpolated maps of $\mathrm{As}, \mathrm{Cr}$, and $\mathrm{Cd}$ concentrations values in the survey area; ranges of concentration are based on the C-A fractal plots held bellow 
772 Figure 5. Interpolated factor score map of the factor $1(\mathrm{~F} 1,5 \mathrm{~A})$, factor $2(\mathrm{~F} 2,5 \mathrm{~B})$, factor $3(\mathrm{~F} 3,5 \mathrm{C})$ and 773 factor $4(F 4,5 D)$. Factor score values ranges are created by means of fractal concentration-area plot 774 (C-A method)

775 Figure 6. Scatterplots between concentration values of $\mathrm{Cu}, \mathrm{Pb}, \mathrm{Zn}, \mathrm{As}, \mathrm{Cr}$ and $\mathrm{Cd}$ (PTEs) with distance from abandoned mining waste deposit (S1); (r) symbolizes Pearson correlation values that highlight the covariate relationship between two variables.

Figure 7. Interpolated baseline map of Cu soils of Taltal city; the plot bellow symbolises Spectrum-Area (S-A) plot for Cu data: the vertical axis represents $\log A(\geq E)$ and the horizontal axis the log-transformed power spectrum value itself; the cut-off indicated by the vertical line was applied to generate the corresponding filter used for geochemical baseline map.

782

Figure 8. Interpolated baseline maps of $\mathrm{Zn}(8 \mathrm{~A}), \mathrm{Pb}(8 \mathrm{~B}), \mathrm{As}(8 \mathrm{C}), \mathrm{Cd}(8 \mathrm{D})$ and $\mathrm{Cr}(8 \mathrm{E})$ concentrations values in soils of our study area

Figure 9. RCCl interpolated and dots map of the 6 considered PTEs; values are expressed in percentage (\%) and red colour symbolises very high contamination level

\section{- Tables}

Table 1. Detection limit, accuracy and precision of the applied analytical method (RPD =relative percent difference). The Precision was calculated as relative percentage difference (\%RPD) using the formula: $\% R P D=[|S V-D V| / S V+D V / 2] \times 100)$, where SV =the original sample value, $D V=$ the duplicate sample value. The laboratory accuracy error was determined using the formula: Accuracy error $=(|X-T V| / T V \times 100)$, where $X=$ laboratory's analysis result for the performance sample (standard) and $\mathrm{TV}=$ true value of the performance sample (standard)

Table 2. Descriptive statistic of 125 topsoils samples from the Taltal urban area, Northern Chile; CV and Std. Deviation are the coefficient of variation (\%) and standard deviation, respectively

Table 3. Mean concentrations values of 6 considered PTES $(\mathrm{mg} / \mathrm{kg})$ in topsoil of the survey area compared to values found in other studies in the recent literature

Table 4. Linear correlation (based on Pearson correlation, $r$ values in black) and the significance of the relationship ( $p$-values $<0.05$, symbolised in red colour) between six PTEs and with the physicochemical properties ( $\mathrm{pH}, \mathrm{EC}$ and redox potential) in soils of Taltal city

801 Table 5. Varimax-rotated factor (four-factor model) of isometric log-ratio ilr back-transformed variables 802 for 125 topsoil samples from the survey area; bold entries: loading values over $|0.50|$ 
Figure 1.
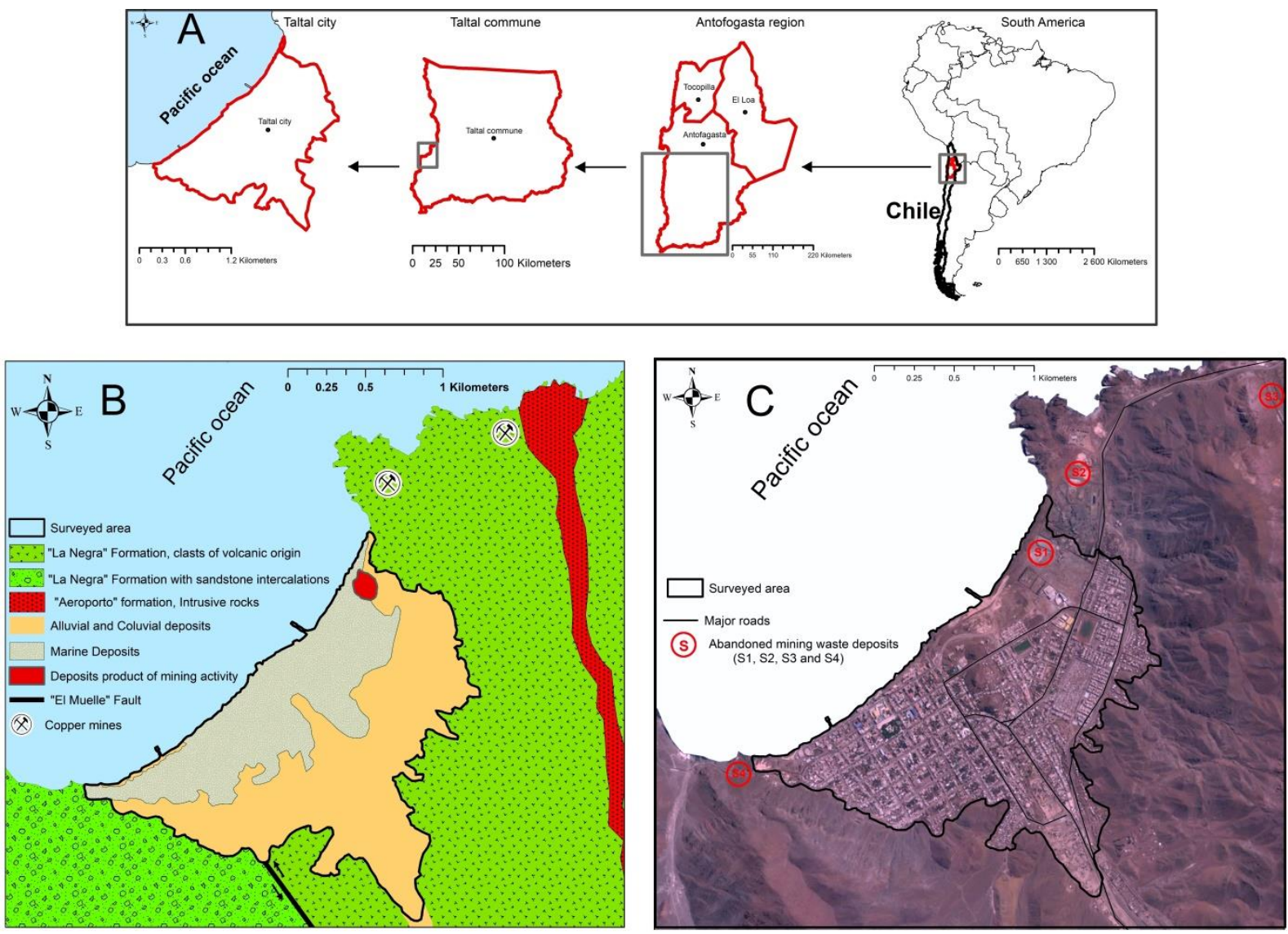
Figure 2.

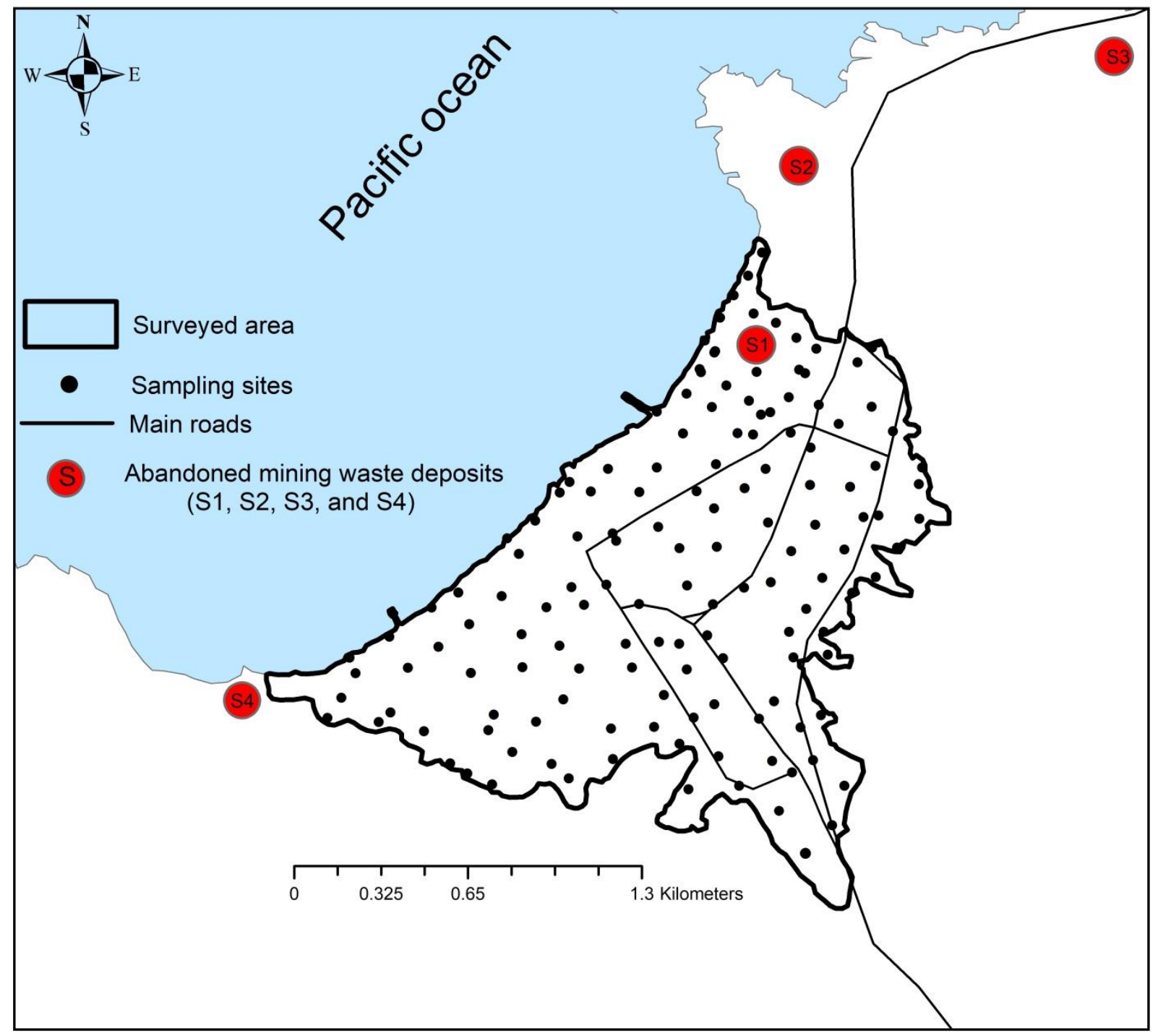


Figure 3.
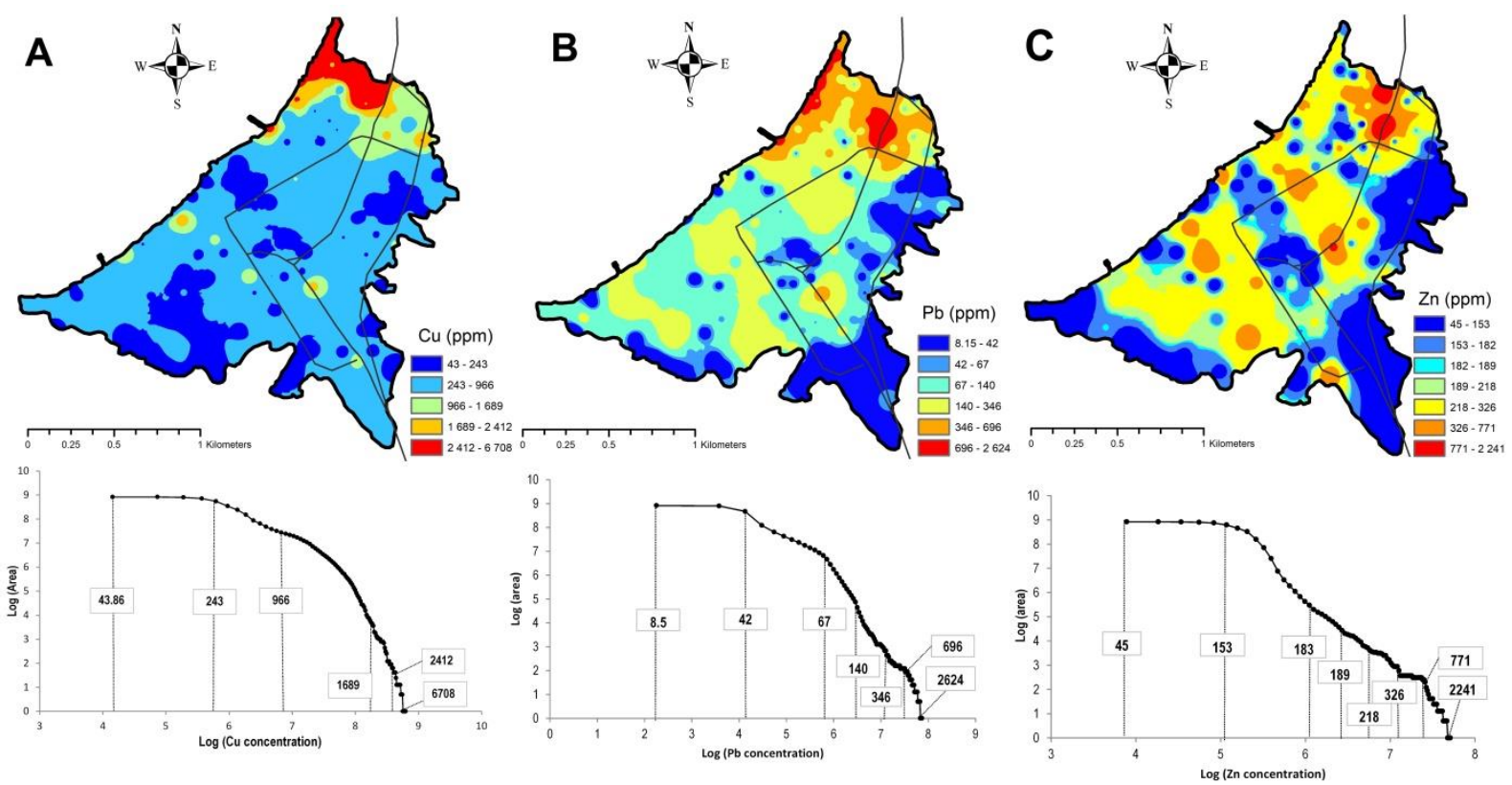
Figure 4

Click here to access/download;Figure;Figure 4.docx $\stackrel{ \pm}{ }$

Figure 4.
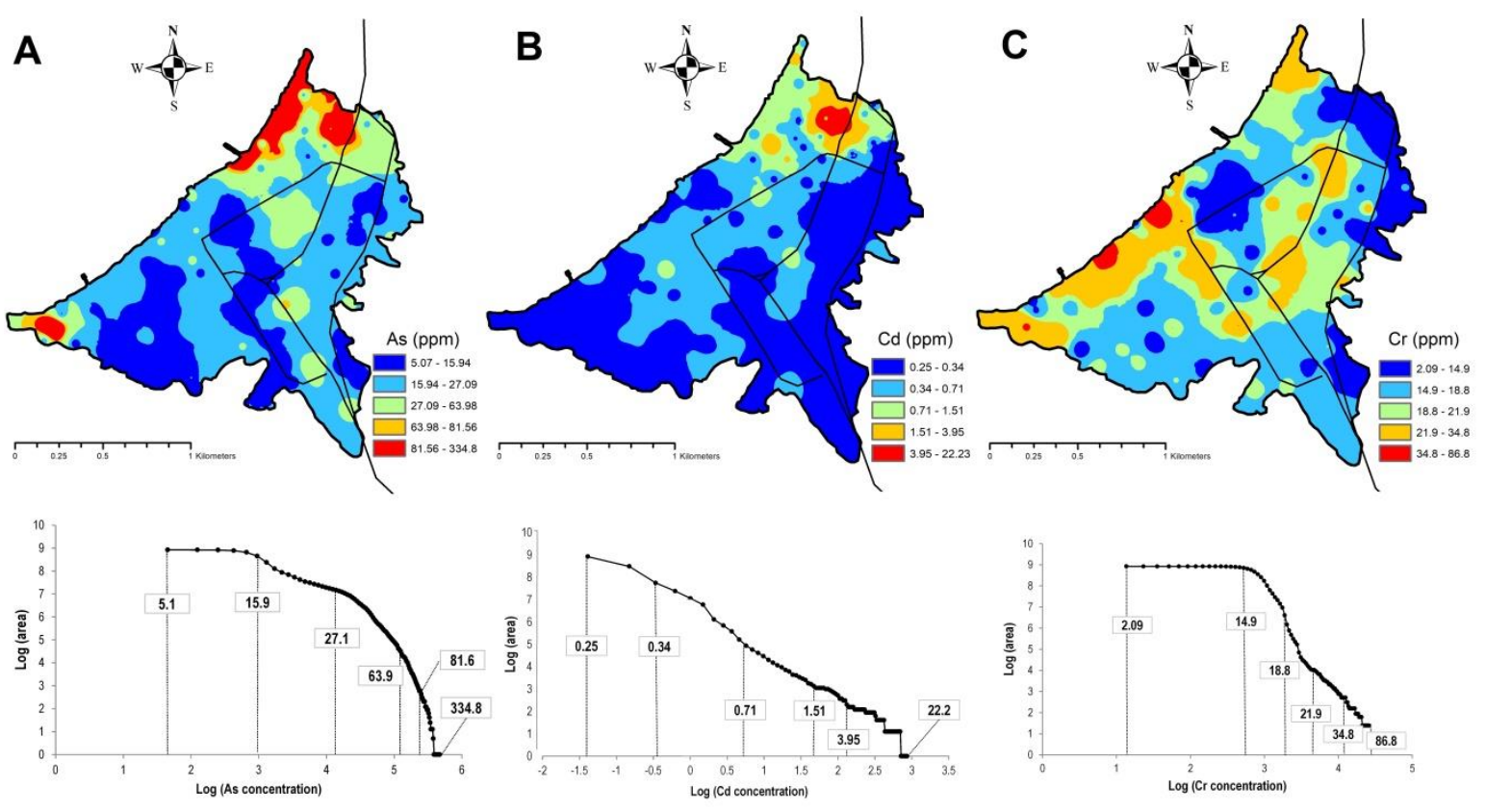
Figure 5.
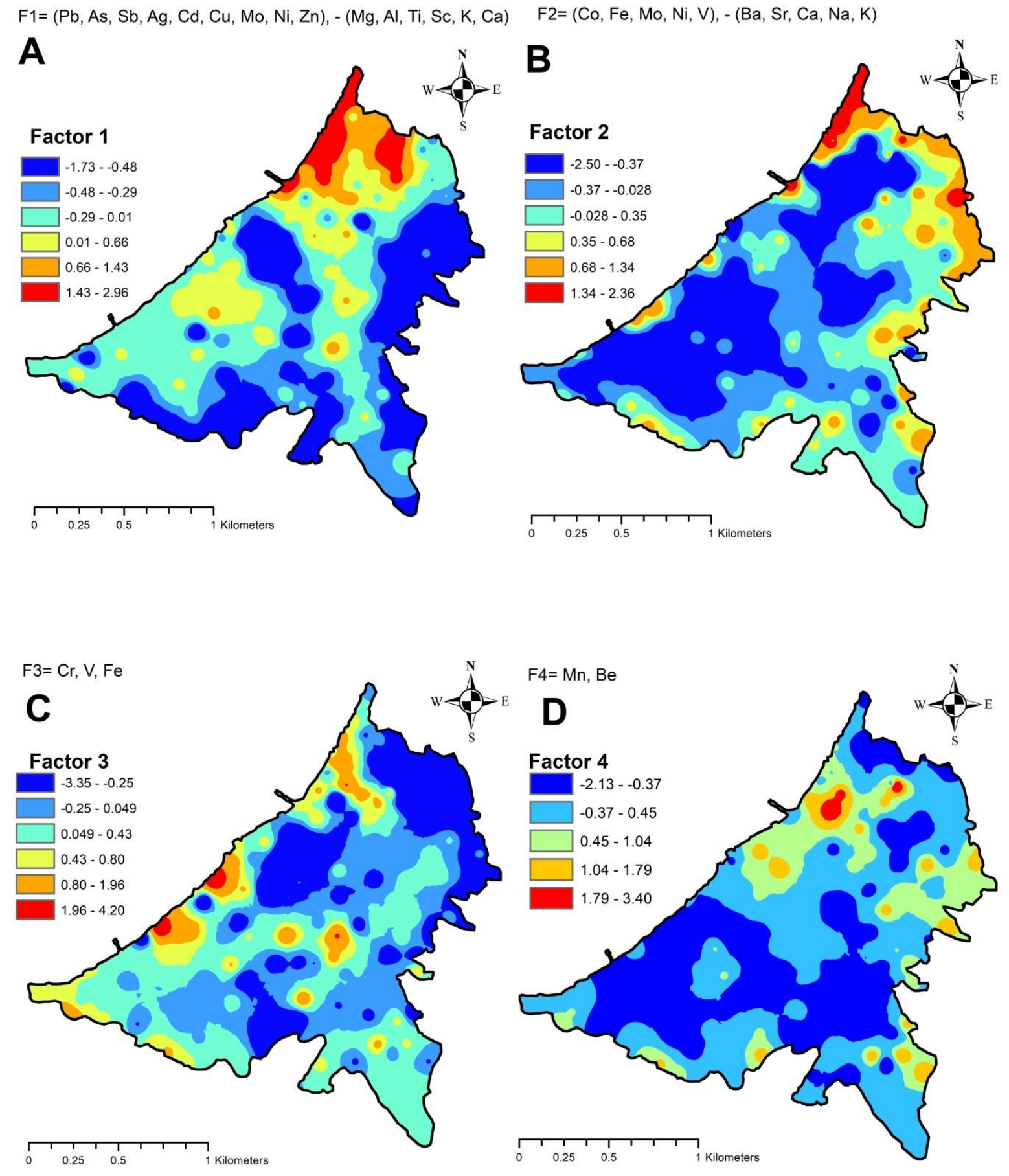


\section{Figure 6.}
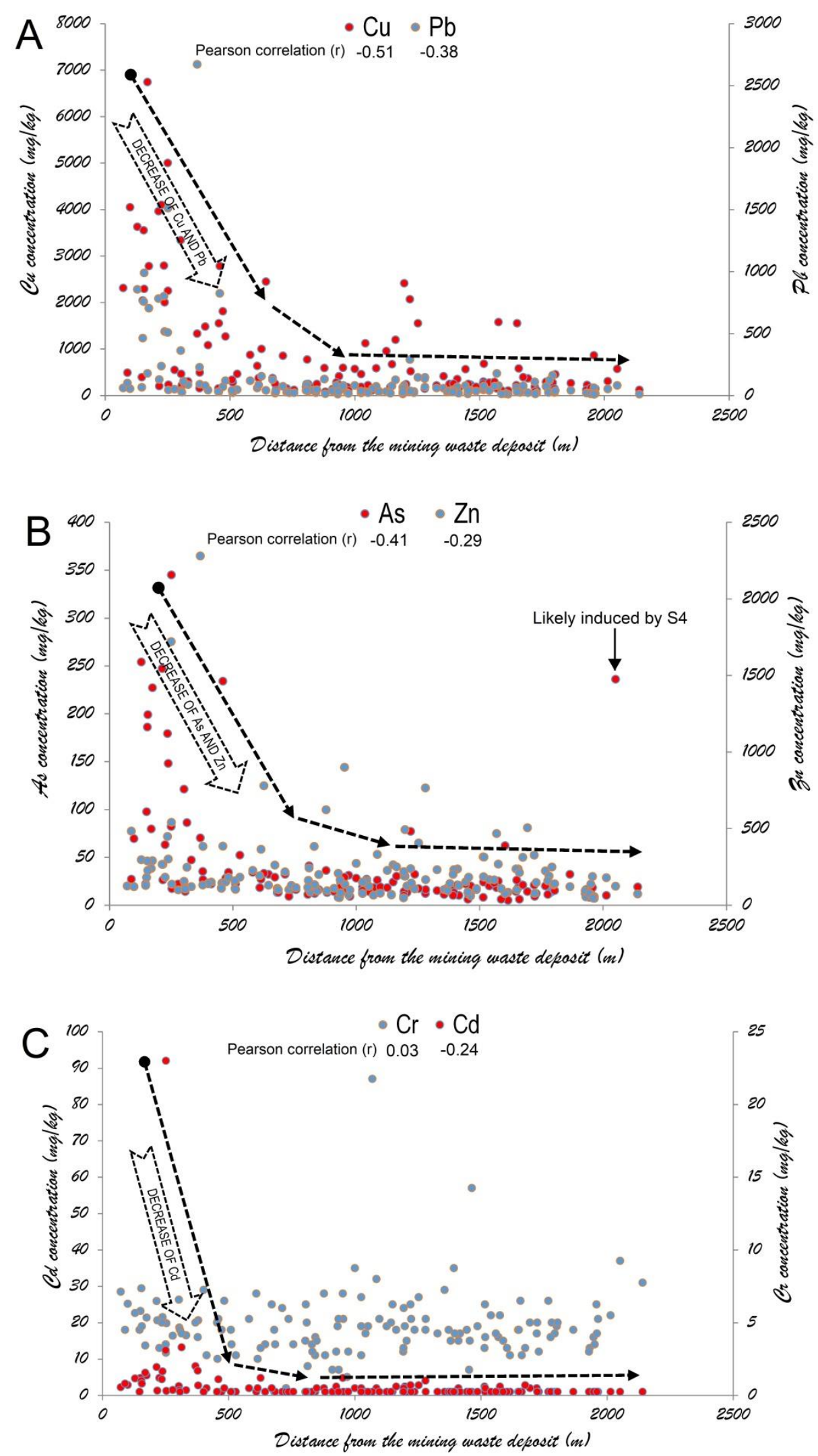
Figure 7.
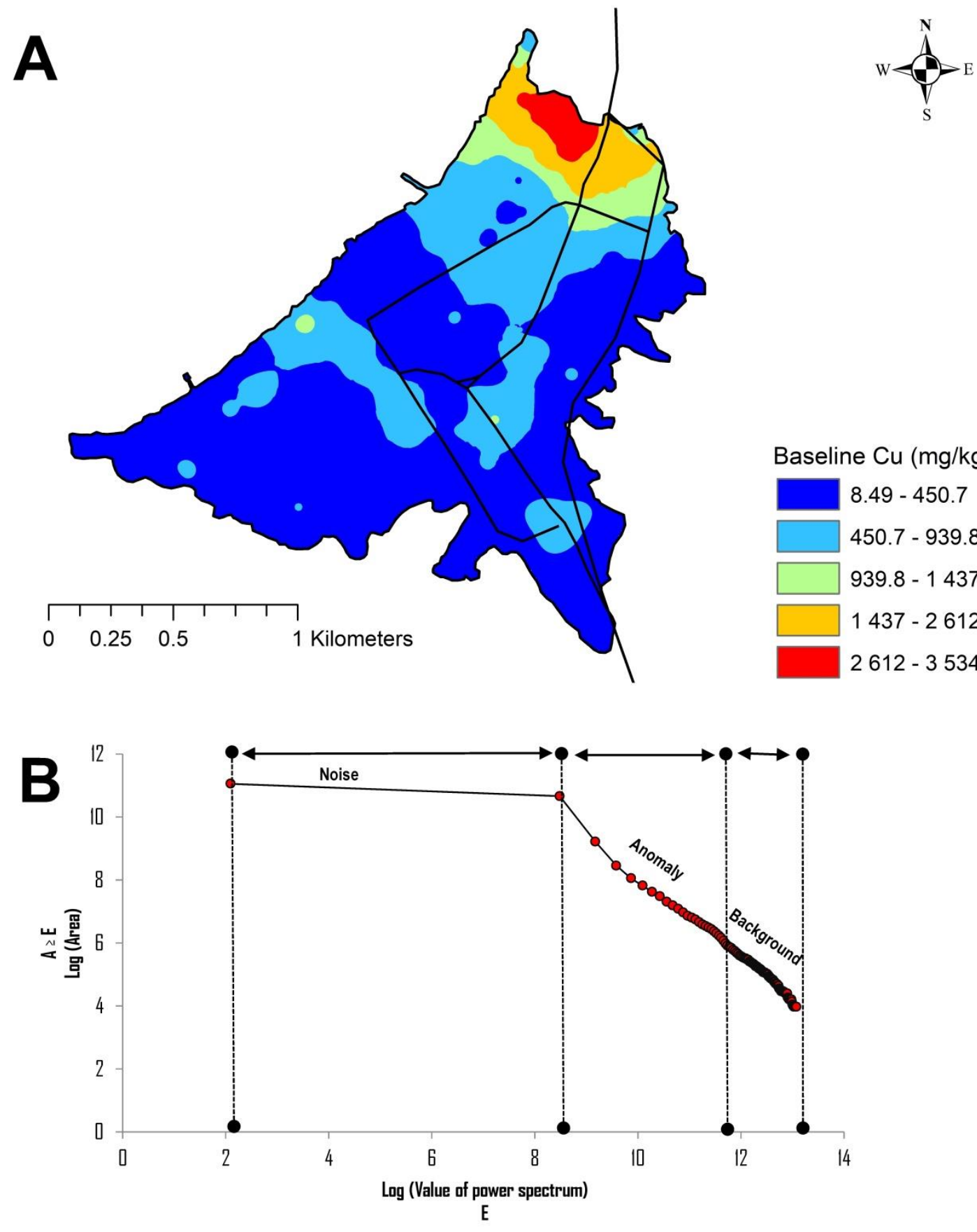

Baseline $\mathrm{Cu}(\mathrm{mg} / \mathrm{kg})$

\ 8.49 - 450.7

$450.7-939.8$

$939.8-1437$

$1437-2612$

$2612-3534$ 
Figure 8.
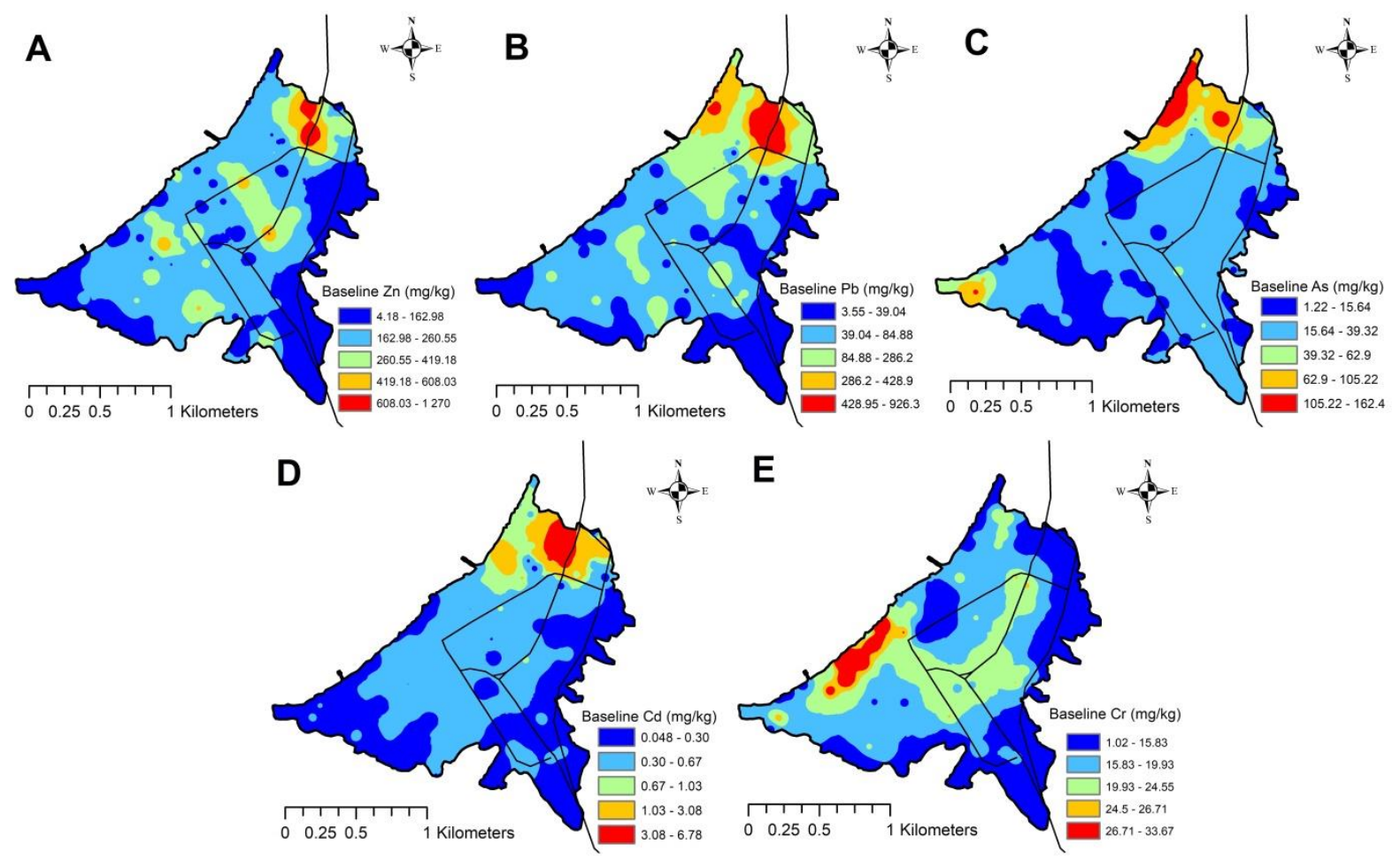
Figure 9.

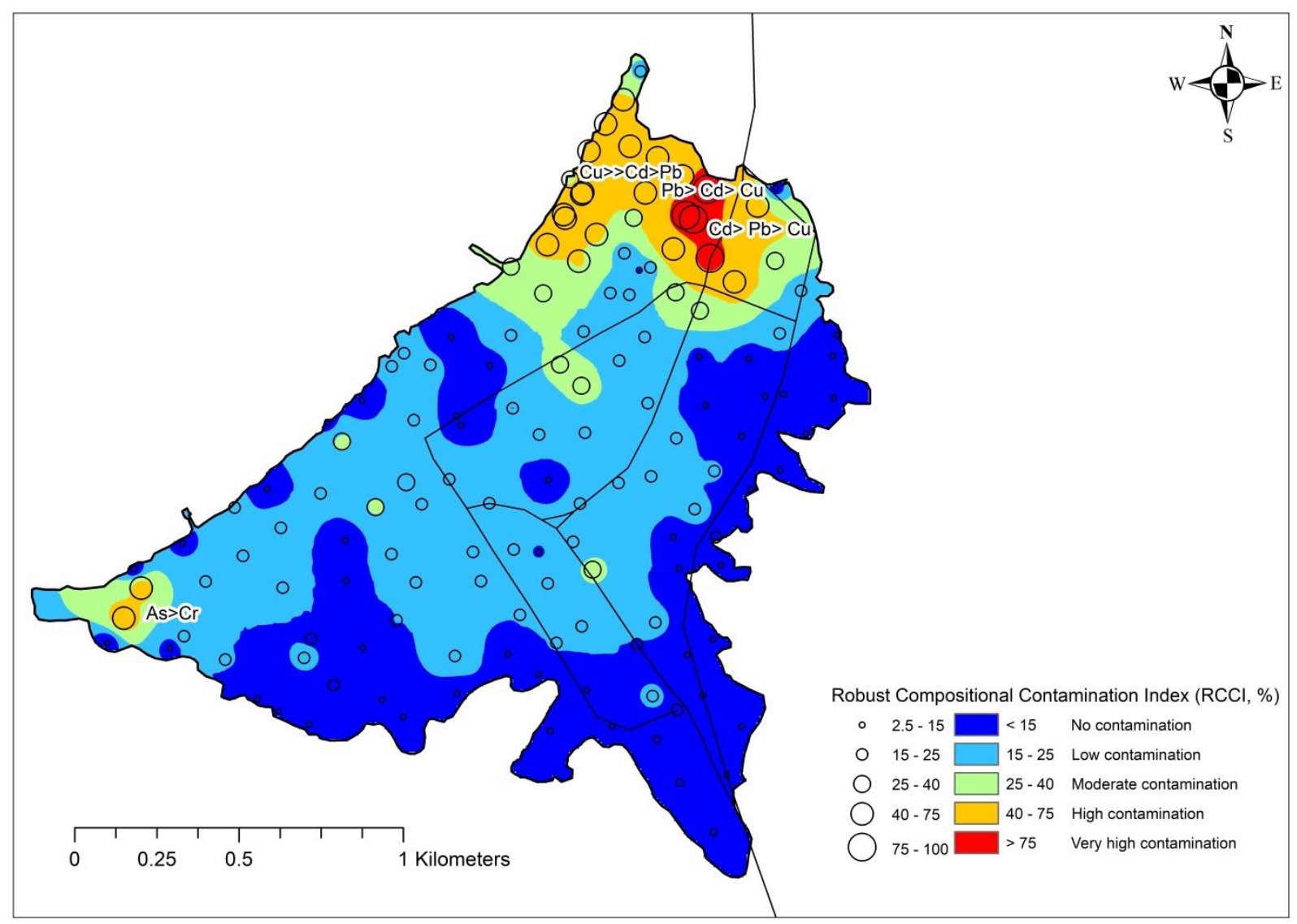


Table 1.

\begin{tabular}{|c|c|c|c|c|}
\hline Elements & Unit & Detection limit (DL) & Accuracy $(\%)$ & Precision (\%RPD) \\
\hline $\mathrm{Al}$ & $\%$ & 0.01 & 1.60 & 1.41 \\
\hline $\mathrm{Ca}$ & $\%$ & 0.01 & 4.82 & 5.06 \\
\hline $\mathrm{Fe}$ & $\%$ & 0.01 & 0.64 & 4.01 \\
\hline K & $\%$ & 0.01 & 1.19 & 6.66 \\
\hline $\mathrm{Mg}$ & $\%$ & 0.01 & 2.83 & 1.99 \\
\hline $\mathrm{Na}$ & $\%$ & 0.01 & 4.55 & 8.32 \\
\hline $\mathrm{Ti}$ & $\%$ & 0.01 & 0.12 & 7.49 \\
\hline $\mathrm{Ag}$ & $\mathrm{mg} / \mathrm{kg}$ & 0.2 & 3.57 & 3.12 \\
\hline As & $\mathrm{mg} / \mathrm{kg}$ & 2 & 2.86 & 13.91 \\
\hline $\mathrm{Ba}$ & $\mathrm{mg} / \mathrm{kg}$ & 10 & 13.33 & 7.49 \\
\hline $\mathrm{Be}$ & $\mathrm{mg} / \mathrm{kg}$ & 0.5 & 0 & 1.12 \\
\hline $\mathrm{Cd}$ & $\mathrm{mg} / \mathrm{kg}$ & 0.5 & 0.99 & 2.21 \\
\hline Co & $\mathrm{mg} / \mathrm{kg}$ & 1 & 3.85 & 9.31 \\
\hline $\mathrm{Cr}$ & $\mathrm{mg} / \mathrm{kg}$ & 1 & 6.82 & 11.44 \\
\hline $\mathrm{Cu}$ & $\mathrm{mg} / \mathrm{kg}$ & 1 & 2.97 & 10.87 \\
\hline $\mathrm{Mn}$ & $\mathrm{mg} / \mathrm{kg}$ & 5 & 1.50 & 2.10 \\
\hline Mo & $\mathrm{mg} / \mathrm{kg}$ & 1 & 22.70 & 0.79 \\
\hline $\mathrm{Ni}$ & $\mathrm{mg} / \mathrm{kg}$ & 1 & 5.00 & 4.03 \\
\hline $\mathrm{Pb}$ & $\mathrm{mg} / \mathrm{kg}$ & 2 & 2.01 & 10.50 \\
\hline $\mathrm{Sb}$ & $\mathrm{mg} / \mathrm{kg}$ & 2 & 5.59 & 13.01 \\
\hline Sc & $\mathrm{mg} / \mathrm{kg}$ & 1 & 0 & 3.85 \\
\hline $\mathrm{Sr}$ & $\mathrm{mg} / \mathrm{kg}$ & 1 & 3.90 & 10.62 \\
\hline V & $\mathrm{mg} / \mathrm{kg}$ & 1 & 0 & 7.95 \\
\hline $\mathrm{Zn}$ & $\mathrm{mg} / \mathrm{kg}$ & 2 & 2.87 & 5.87 \\
\hline
\end{tabular}


Table 2.

\begin{tabular}{|c|c|c|c|c|c|c|c|c|c|}
\hline Variable & Unit & Minimum & Maximum & Mean & Median & CV (\%) & Std Deviation & Skewness & Kurtosis \\
\hline Redox potential & $\mathrm{mV}$ & 92.10 & 279 & 183.04 & 184.80 & 19.8 & 36.15 & -0.05 & -0.11 \\
\hline $\mathrm{pH}$ & - & 6.86 & 9.89 & 7.91 & 7.88 & 7.5 & 0.59 & 0.44 & 0.27 \\
\hline $\mathrm{EC}(\mu \mathrm{S} / \mathrm{cm})$ & $\mu S / c m$ & 13 & 109400 & 12550 & 8320 & 115.4 & 14483 & 2.83 & 13.37 \\
\hline $\mathrm{Ag}$ & $\mathrm{mg} / \mathrm{kg}$ & 0.1 & 10.9 & 0.65 & 0.3 & 180.2 & 1.16 & 5.83 & 43.49 \\
\hline $\mathrm{Al}$ & $\mathrm{mg} / \mathrm{kg}$ & 3700 & 35800 & 15756 & 14800 & 36.2 & 5704 & 0.88 & 1.07 \\
\hline As & $\mathrm{mg} / \mathrm{kg}$ & 5 & 345 & 37.85 & 18.85 & 149.6 & 56.63 & 3.21 & 10.27 \\
\hline $\mathrm{Ba}$ & $\mathrm{mg} / \mathrm{kg}$ & 20 & 1680 & 124.57 & 80 & 137.3 & 171.02 & 6.18 & 48.74 \\
\hline $\mathrm{Be}$ & $\mathrm{mg} / \mathrm{kg}$ & 0.25 & 1.10 & 0.40 & 0.46 & 41.9 & 0.17 & 1.06 & 1.75 \\
\hline $\mathrm{Ca}$ & $\mathrm{mg} / \mathrm{kg}$ & 3100 & 46100 & 19266 & 18800 & 38.0 & 7327 & 0.60 & 1.10 \\
\hline $\mathrm{Cd}$ & $\mathrm{mg} / \mathrm{kg}$ & 0.25 & 23 & 0.64 & 0.25 & 305.4 & 1.95 & 10.75 & 120.23 \\
\hline Co & $\mathrm{mg} / \mathrm{kg}$ & 8 & 77.10 & 20.58 & 17 & 58.3 & 11.99 & 2.43 & 6.34 \\
\hline $\mathrm{Cr}$ & $\mathrm{mg} / \mathrm{kg}$ & 2 & 87 & 19.26 & 18 & 46.5 & 8.96 & 3.60 & 23.26 \\
\hline $\mathrm{Cu}$ & $\mathrm{mg} / \mathrm{kg}$ & 39 & 6740 & 766.82 & 285 & 144.4 & 1107 & 2.58 & 7.51 \\
\hline $\mathrm{Fe}$ & $\mathrm{mg} / \mathrm{kg}$ & 23700 & 373000 & 54734 & 42500 & 82.3 & 45039 & 4.37 & 22.20 \\
\hline K & $\mathrm{mg} / \mathrm{kg}$ & 500 & 5800 & 2080 & 2000 & 40.6 & 843.88 & 0.91 & 2.23 \\
\hline $\mathrm{Mg}$ & $\mathrm{mg} / \mathrm{kg}$ & 2400 & 29200 & 13404 & 12600 & 38.3 & 5137 & 0.67 & 0.30 \\
\hline $\mathrm{Mn}$ & $\mathrm{mg} / \mathrm{kg}$ & 336 & 12850 & 865.44 & 670 & 158.2 & 1369 & 8.01 & 64.02 \\
\hline Mo & $\mathrm{mg} / \mathrm{kg}$ & 1 & 386 & 8.21 & 3.00 & 398.8 & 32.74 & 10.96 & 123.63 \\
\hline $\mathrm{Na}$ & $\mathrm{mg} / \mathrm{kg}$ & 300 & 37900 & 5714.37 & 4700 & 93.3 & 5333 & 2.49 & 9.83 \\
\hline $\mathrm{Ni}$ & $\mathrm{mg} / \mathrm{kg}$ & 2 & 192 & 21.05 & 14 & 118.8 & 24.99 & 4.10 & 19.68 \\
\hline $\mathrm{Pb}$ & $\mathrm{mg} / \mathrm{kg}$ & 8 & 2670 & 135.30 & 45.40 & 225.5 & 305.02 & 5.33 & 35.42 \\
\hline $\mathrm{Sb}$ & $\mathrm{mg} / \mathrm{kg}$ & 1 & 42.90 & 3.88 & 1 & 186.4 & 7.24 & 3.25 & 10.59 \\
\hline Sc & $\mathrm{mg} / \mathrm{kg}$ & 0.30 & 15 & 6.08 & 6 & 50.1 & 3.04 & 0.40 & 0.14 \\
\hline $\mathrm{Sr}$ & $\mathrm{mg} / \mathrm{kg}$ & 19 & 227 & 65.45 & 59 & 54.9 & 35.94 & 1.69 & 4.19 \\
\hline $\mathrm{Ti}$ & $\mathrm{mg} / \mathrm{kg}$ & 300 & 4000 & 1598.48 & 1315 & 50.9 & 814 & 0.96 & 0.41 \\
\hline V & $\mathrm{mg} / \mathrm{kg}$ & 58 & 663 & 120.97 & 105 & 59 & 71.31 & 4.78 & 27.80 \\
\hline $\mathrm{Zn}$ & $\mathrm{mg} / \mathrm{kg}$ & 45 & 2280 & 224.12 & 157 & 115.1 & 258.01 & 5.28 & 34.62 \\
\hline
\end{tabular}


Table 3.

Urban areas

As $\quad \mathrm{Cd}$

$\begin{array}{llll}\mathrm{Cr} & \mathrm{Cu} & \mathrm{Pb} & \mathrm{Zn}\end{array}$

Authors

South America

$\begin{array}{llllllll}\text { Chile } & \text { Taltal } & 37.85 & 0.64 & 19.26 & 766.82 & 135.3 & 224.12\end{array}$

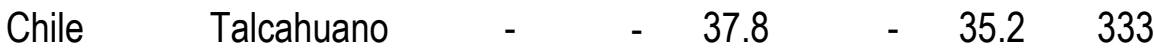

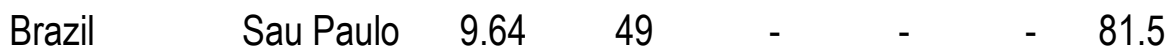

Asia

China

China

Yibin City 10.55

$\begin{array}{lllll}- & - & 51.63 & 61.23 & 138.88\end{array}$

$\begin{array}{llllll}\text { Hong kong } & 0.62 & 23.1 & 23.3 & 94.6 & 125\end{array}$

Mongolia

Ulaanbaatar

$\begin{array}{llll}14 & 0.8 & 20.3 & 35.9\end{array}$

$63.9 \quad 158.7$

This study

Tume et al. 2008

Figueiredo et al. 2007

Africa

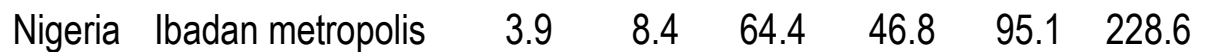

Algeria

Tunisia

Annaba

$\begin{array}{llllll}- & 0.44 & 30.9 & 39 & 53.1 & 67.5\end{array}$

$\begin{array}{lllllll}\text { Sfax } & - & - & 17.5 & 15.6 & 30.23 & 36.5\end{array}$

Odewande et al. 2006

Maas et al. 2010

Wali et al. 2013

\section{Europe}

Italy

Scotland

Naples

$12.4 \quad 0.5$

$0.5 \quad 12$

52

163100

142

$\begin{array}{lll}62 & 195 & 178\end{array}$

$\begin{array}{lllllll}\text { Palermo } & 23 & 2 & 95.4 & 146.6 & 218.2 & 516\end{array}$

Cicchella et al. 2005

Italy

95.4

Ajmone-Marsan et al. 2008

Manta et al. 2002 


\section{Table 4.}

\begin{tabular}{|c|c|c|c|c|c|c|c|c|c|}
\hline & \multicolumn{3}{|c|}{ Physico-chemical parameters } & \multicolumn{6}{|c|}{ Elements } \\
\hline & Redox & $\mathrm{pH}$ & $\mathrm{EC}$ & As & $\mathrm{Cd}$ & $\mathrm{Cr}$ & $\mathrm{Cu}$ & $\mathrm{Pb}$ & $\mathrm{Zn}$ \\
\hline Redox & & & & -0.3031 & -0.2413 & 0.1664 & -0.4776 & -0.4933 & -0.4259 \\
\hline $\mathrm{pH}$ & & & & -0.5545 & -0.4376 & 0.3251 & -0.6583 & -0.7356 & -0.4722 \\
\hline EC & & & & -0.1823 & -0.2445 & 0.0935 & -0.1333 & -0.0931 & -0.0748 \\
\hline As & $0.0002^{\star * *}$ & $0.00^{* * *}$ & $0.0299^{*}$ & & 0.5081 & -0.1294 & 0.6054 & 0.6873 & 0.0533 \\
\hline Cd & $0.0038^{* *}$ & $0.00^{* * *}$ & $0.0034^{* *}$ & $0.00^{* * *}$ & & -0.2706 & 0.3769 & 0.6038 & 0.3899 \\
\hline $\mathrm{Cr}$ & $0.0478^{*}$ & $0.0001^{* * *}$ & 0.2685 & 0.1248 & $0.0011^{* *}$ & & -0.178 & -0.2066 & -0.2031 \\
\hline $\mathrm{Cu}$ & $0.00^{* * *}$ & $0.00^{* * *}$ & 0.1137 & $0.00^{* * *}$ & $0.00^{* * *}$ & $0.0341^{*}$ & & 0.6137 & 0.2278 \\
\hline $\mathrm{Pb}$ & $0.00^{* * *}$ & $0.00^{* * *}$ & 0.2707 & $0.00^{* * *}$ & $0.00^{* * *}$ & $0.0136^{*}$ & $0.00^{\star \star *}$ & & 0.4812 \\
\hline $\mathrm{Zn}$ & $0.00^{* * *}$ & $0.00^{* * *}$ & 0.3765 & 0.5284 & $0.00^{* * *}$ & $0.0154^{*}$ & $0.0064^{* *}$ & $0.00^{* * *}$ & \\
\hline
\end{tabular}

* Significant correlation at $p<0.05$

${ }^{* *}$ Significant correlation at $p<0.01$

*** Significant correlation at $p<0.001$ 
Table 5.

\begin{tabular}{|c|c|c|c|c|c|}
\hline \multirow[b]{2}{*}{ Variables } & \multicolumn{4}{|c|}{ Factors } & \multirow[b]{2}{*}{ Communalities } \\
\hline & F1 & $\mathrm{F} 2$ & F3 & $\mathrm{F} 4$ & \\
\hline $\mathrm{Ag}$ & 0.76 & 0.10 & -0.31 & -0.19 & 0.72 \\
\hline $\mathrm{Al}$ & -0.85 & 0.00 & -0.12 & 0.37 & 0.87 \\
\hline As & 0.79 & 0.28 & -0.03 & 0.17 & 0.74 \\
\hline $\mathrm{Ba}$ & 0.22 & -0.77 & 0.11 & 0.09 & 0.67 \\
\hline $\mathrm{Be}$ & -0.15 & 0.29 & 0.30 & 0.66 & 0.63 \\
\hline $\mathrm{Ca}$ & -0.65 & -0.53 & -0.03 & 0.04 & 0.71 \\
\hline $\mathrm{Cd}$ & 0.70 & -0.06 & -0.30 & 0.35 & 0.71 \\
\hline Co & 0.10 & 0.82 & 0.23 & 0.18 & 0.77 \\
\hline $\mathrm{Cr}$ & -0.04 & -0.10 & 0.81 & -0.22 & 0.72 \\
\hline $\mathrm{Cu}$ & 0.65 & 0.38 & -0.30 & -0.32 & 0.75 \\
\hline $\mathrm{Fe}$ & 0.21 & 0.73 & 0.51 & 0.17 & 0.86 \\
\hline $\mathrm{K}$ & -0.70 & -0.50 & -0.12 & 0.07 & 0.76 \\
\hline $\mathrm{Mg}$ & -0.85 & -0.03 & -0.12 & 0.33 & 0.84 \\
\hline $\mathrm{Mn}$ & -0.34 & -0.03 & -0.28 & 0.69 & 0.67 \\
\hline Mo & 0.63 & 0.50 & -0.08 & -0.31 & 0.75 \\
\hline $\mathrm{Na}$ & -0.27 & -0.50 & 0.08 & -0.42 & 0.51 \\
\hline $\mathrm{Ni}$ & 0.52 & 0.50 & 0.43 & 0.02 & 0.71 \\
\hline $\mathrm{Pb}$ & 0.88 & 0.05 & -0.16 & -0.03 & 0.80 \\
\hline $\mathrm{Sb}$ & 0.76 & 0.24 & -0.15 & 0.32 & 0.77 \\
\hline Sc & -0.78 & 0.21 & -0.18 & -0.01 & 0.69 \\
\hline $\mathrm{Sr}$ & -0.25 & -0.76 & 0.01 & -0.09 & 0.65 \\
\hline $\mathrm{Ti}$ & -0.82 & 0.02 & -0.11 & 0.28 & 0.77 \\
\hline V & -0.12 & 0.50 & 0.72 & 0.19 & 0.82 \\
\hline $\mathrm{Zn}$ & 0.50 & -0.39 & -0.33 & -0.12 & 0.53 \\
\hline Eigenvalues & 9.15 & 4.42 & 2.21 & 1.39 & \\
\hline Total variance in \% & 34.18 & 18.34 & 10.02 & 8.67 & \\
\hline Cum. of total variance & 34.18 & 53.03 & 63.05 & 71.73 & \\
\hline
\end{tabular}




\section{Rebut}

To the reviewers' comments on manuscript titled

\section{Source patterns of Potentially Toxic Elements (PTEs) and mining activity contamination level in} soils of Taltal city (Northern Chile)

EGAH-D-19-00276R1

Arturo Reyes, Matar Thiombane, Antonio Panico, Linda Daniele, Annamaria Lima, Marcello Di Bonito, Benedetto De Vivo

Dear Mr THIOMBANE,

We have received the reports from our advisors on your manuscript, "Source patterns of Potentially Toxic Elements (PTEs) and mining activity contamination level in soils of Taltal city (Northern Chile)", submitted to Environmental Geochemistry and Health.

Based on the advice received, I have decided that your manuscript can be accepted for publication after you have carried out the corrections as suggested by the reviewer(s).

Please respond to the reviewer's comments on a point-by-point basis indicating the page and line numbers where the amendments have been made, and highlighting the changes in the revised manuscript.

Attached, please find the reviewers' comments for your perusal.

With kind regards,

Springer Journal's Editorial Office

Environmental Geochemistry and Health

\section{Reviewer's comments and authors responses}

Dear Journal Editorial Officers,

First of all we would like to thank you for accepting the manuscript and appreciate the reviewer's comments and suggestions, which helped us to improve our paper substantially. As indicated below, we have checked all the general and specific comments provided by the reviewers and have made changes accordingly to their indications.

Kind regards,

Arturo Reyes, Matar Thiombane, Antonio Panico, Linda Daniele, Annamaria Lima, Marcello Di Bonito, Benedetto De Vivo 


\section{Reviewer \#1}

This manuscript is a well-structure paper and can be published on this journal. I have minor comments and suggestions as below:

Comment (1): I was satisfied with this revision. However, the C-A and S-A fractal/multifractal models, and MIDW were used in this study. The state-of-art of these models should be introduced in the section of methods.

Response to comment (1): Dear reviewer, thank you for your comments. We have modified and complemented our manuscript based on your suggestions, by adding the materials that highlight stateof-art of the C-A and S-A fractal/multifractal, and MIDW models. See section 2.4.1. Spatial distribution and baseline values of PTEs (207 to 252).

Comment (2) Please note the similarity of your manuscript $=35 \%$. Could you please lower the similarity to about $20 \%$ ?

Response to comment (2): Thank you for your suggestions and the similarity is decrease as lower as possible. See new version of the manuscript. 